\title{
Rapid chemical evolution of tropospheric volcanic emissions from Redoubt $\square$ crossMark Volcano, Alaska, based on observations of ozone and halogen-containing gases
}

\author{
Peter J. Kelly ${ }^{\text {a,* }}$, Christoph Kern a , Tjarda J. Roberts ${ }^{\text {b }}$, Taryn Lopez ${ }^{\text {c,d }}$, \\ Cynthia Werner ${ }^{\mathrm{e}}$, Alessandro Aiuppa ${ }^{\mathrm{f}, \mathrm{g}}$ \\ a Cascades Volcano Observatory, Volcano Science Center, U.S. Geological Survey, 1300 SE Cardinal Court, Vancouver, WA 98683, USA \\ b TJ Roberts Research, 21 Karl Halls vei, 9012 Tromsø, Norway \\ c Alaska Volcano Observatory, Geophysical Institute, University of Alaska Fairbanks, 903 Koyukuk Drive, Fairbanks, AK 99775, USA \\ d Department of Chemistry and Biochemistry, University of Alaska Fairbanks, 900 Yukon Drive, Fairbanks, AK 99775, USA \\ e Alaska Volcano Observatory, Volcano Science Center, U.S. Geological Survey, 4200 University Drive, Anchorage, AK 9950, USA \\ f DiSTeM, Università di Palermo, Via Archirafi 36, 90123 Palermo, Italy \\ g Istituto Nazionale di Geofisica e Vulcanologia, sezione di Palermo, Via La Malfa 153, 90146 Palermo, Italy
}

\section{A R T I C L E I N F O}

\section{Article history:}

Received 6 June 2011

Accepted 20 April 2012

Available online 28 April 2012

\section{Keywords:}

Volcanic plume

Ozone depletion

Bromine monoxide

Reactive halogen

Sub arctic troposphere

Chemical evolution

\begin{abstract}
A B S T R A C T
We report results from an observational and modeling study of reactive chemistry in the tropospheric plume emitted by Redoubt Volcano, Alaska. Our measurements include the first observations of $\mathrm{Br}$ and I degassing from an Alaskan volcano, the first study of $\mathrm{O}_{3}$ evolution in a volcanic plume, as well as the first detection of $\mathrm{BrO}$ in the plume of a passively degassing Alaskan volcano. This study also represents the first detailed spatially-resolved comparison of measured and modeled $\mathrm{O}_{3}$ depletion in a volcanic plume. The composition of the plume was measured on June 20, 2010 using base-treated filter packs (for F, $\mathrm{Cl}, \mathrm{Br}$, I, and S) at the crater rim and by an instrumented fixed-wing aircraft on June 21 and August 19, 2010. The aircraft was used to track the chemical evolution of the plume up to $30 \mathrm{~km}$ downwind ( $2 \mathrm{~h}$ plume travel time) from the volcano and was equipped to make in situ observations of $\mathrm{O}_{3}$, water vapor, $\mathrm{CO}_{2}, \mathrm{SO}_{2}$, and $\mathrm{H}_{2} \mathrm{~S}$ during both flights plus remote spectroscopic observations of $\mathrm{SO}_{2}$ and $\mathrm{BrO}$ on the August 19th flight. The airborne data from June 21 reveal rapid chemical $\mathrm{O}_{3}$ destruction in the plume as well as the strong influence chemical heterogeneity in background air had on plume composition. Spectroscopic retrievals from airborne traverses made under the plume on August 19 show that $\mathrm{BrO}$ was present $\sim 6 \mathrm{~km}$ downwind (20 min plume travel time) and in situ measurements revealed several ppbv of $\mathrm{O}_{3}$ loss near the center of the plume at a similar location downwind. Simulations with the PlumeChem model reproduce the timing and magnitude of the observed $\mathrm{O}_{3}$ deficits and suggest that autocatalytic release of reactive bromine and in-plume formation of BrO were primarily responsible for the observed $\mathrm{O}_{3}$ destruction in the plume. The measurements are therefore in general agreement with recent model studies of reactive halogen formation in volcanic plumes, but also show that field studies must pay close attention to variations in the composition of ambient air entrained into volcanic plumes in order to unambiguously attribute observed $\mathrm{O}_{3}$ anomalies to specific chemical or dynamic processes. Our results suggest that volcanic eruptions in Alaska are sources of reactive halogen species to the subarctic troposphere.
\end{abstract}

Published by Elsevier B.V.

\section{Introduction}

Understanding the chemistry of tropospheric volcanic plumes is important for evaluating eruption hazards and to assess the atmospheric and environmental impacts of volcanic emissions. Recent studies have shown that tropospheric volcanic plumes are chemically active and that relatively non-reactive hydrogen halide gases (e.g. hydrogen bromide, $\mathrm{HBr}$ ) emitted from volcanoes can be rapidly converted into

\footnotetext{
* Corresponding author. Tel.: +1 360993 8950; fax: +1 3609938980 E-mail address: pkelly@usgs.gov (P.J. Kelly).
}

reactive halogen species (e.g. bromine monoxide, $\mathrm{BrO}$ ) by in-plume heterogeneous chemical processes (Bobrowski et al., 2003; Gerlach, 2004; Oppenheimer et al., 2006; Bobrowski and Platt, 2007; Bobrowski et al., 2007; Bani et al., 2009; Kern et al., 2009). The formation of $\mathrm{BrO}$ in volcanic plumes is notable because it is linked to families of chemical reactions known to profoundly impact tropospheric chemistry (von Glasow et al., 2009; von Glasow, 2010). Reactive halogen species ( $\mathrm{X}, \mathrm{XO}, \mathrm{X}_{2}, \mathrm{XY}, \mathrm{OXO}, \mathrm{HOX}, \mathrm{XONO}_{2}, \mathrm{XNO}_{2}$, where $\mathrm{X}, \mathrm{Y}=\mathrm{Cl}, \mathrm{Br}$, or I), especially those that contain bromine, can rapidly destroy ozone $\left(\mathrm{O}_{3}\right)$, alter common atmospheric oxidation pathways, and increase the deposition of toxic metals like mercury to the surface (e.g. Simpson et al., 2007; von Glasow, 2010). 
The main chemical reaction sequence thought to be responsible for activation of $\mathrm{Br}$ and formation of $\mathrm{BrO}$ in volcanic plumes is conceptually similar to the autocatalytic "bromine explosion" mechanism that leads to polar tropospheric $\mathrm{O}_{3}$ depletion events (see Roberts et al., 2009 and von Glasow et al., 2009 for more thorough descriptions of reactive halogen chemistry in volcanic plumes and Simpson et al., 2007 for a review of polar halogen chemistry), as summarized below:

$$
\begin{aligned}
& \mathrm{HOBr}_{(\mathrm{gas})} \rightarrow \mathrm{HOBr}_{(\mathrm{aq})} \\
& \mathrm{HBr}_{(\mathrm{gas})} \rightarrow \mathrm{Br}^{-}{ }_{(\mathrm{aq})}+\mathrm{H}^{+}(\mathrm{aq}) \\
& \operatorname{HOBr}_{(\mathrm{aq})}+\mathrm{Br}^{-}{ }_{(\mathrm{aq})}+\mathrm{H}^{+}(\mathrm{aq}) \rightarrow \mathrm{Br}_{2(\mathrm{gas})}+\mathrm{H}_{2} \mathrm{O}_{(\mathrm{aq})} \\
& \mathrm{Br}_{2}+\mathrm{h} \nu \rightarrow 2 \mathrm{Br} \\
& 2\left(\mathrm{Br}+\mathrm{O}_{3} \rightarrow \mathrm{BrO}+\mathrm{O}_{2}\right) \\
& \mathrm{BrO}+\mathrm{BrO} \rightarrow 2 \mathrm{Br}+\mathrm{O}_{2} \\
& \mathrm{BrO}+\mathrm{BrO} \rightarrow \mathrm{Br}_{2}+\mathrm{O}_{2} \\
& \mathrm{BrO}+\mathrm{HO}_{2} \rightarrow \mathrm{HOBr}+\mathrm{O}_{2}
\end{aligned}
$$

According to this mechanism, gaseous $\mathrm{HOBr}$ and $\mathrm{HBr}$ are taken up onto acidic particles $(\mathrm{pH}<6 ; \mathrm{R} 1$ and $\mathrm{R} 2)$ and an acid-catalyzed aqueous-phase reaction results in $\mathrm{Br}_{2}$ that is released to the gas phase (R3). Rapid photolysis of $\mathrm{Br}_{2}$ (R4) and subsequent reaction with $\mathrm{O}_{3}$ yields $\mathrm{BrO}$ (R5). Further $\mathrm{O}_{3}$ destruction can be sustained by the $\mathrm{BrO}$ self-reaction (R6a, R6b), and reaction of $\mathrm{BrO}$ with $\mathrm{HO}_{2}$ (R7) allows the cycle to repeat. Each autocatalytic cycle doubles the $\mathrm{BrO}$ concentration which can lead to rapid, non-linear increases of $\mathrm{BrO}$ in volcanic plumes and significant $\mathrm{O}_{3}$ destruction.

The idea that in-plume $\mathrm{BrO}$ formation and $\mathrm{O}_{3}$ destruction could be important aspects of volcanic plume chemistry was first proposed by Bobrowski et al. (2003), evaluated from a high-temperature thermodynamic perspective by Gerlach (2004), and assessed from a kinetic standpoint by Oppenheimer et al. (2006). The presence of $\mathrm{BrO}$ has been detected by ultraviolet differential optical absorption spectroscopy (UV-DOAS) in the plumes of at least 10 volcanoes worldwide (see Boichu et al. (2011) and references therein for data compiled from 9 volcanoes; more recently Heue et al. (2011) reported detection of $\mathrm{BrO}$ in the plume from Eyjafjallajökull volcano). In addition, Theys et al. (2009) reported satellite identification of $\mathrm{BrO}$ in the upper tropospheric/lower stratospheric eruptive plume from the 2009 eruption of Kasatochi volcano, Alaska. Numerical models have also predicted extensive $\mathrm{O}_{3}$ destruction in volcanic plumes due mainly to in-plume BrO formation (Bobrowski et al., 2007; Roberts et al., 2009; von Glasow, 2010).

Despite these recent advances, observations of $\mathrm{O}_{3}$ in volcanic plumes have been relatively sparse and empirical correlations of $\mathrm{BrO}$ formation and $\mathrm{O}_{3}$ destruction have been challenging to obtain. A few older studies each reported $\mathrm{O}_{3}$ depletion in volcanic plumes (Stith et al., 1978; Fruchter et al., 1980; Hobbs et al., 1982) but did not offer much detail or discussion to accompany their observations, which limited their utility. Several recent studies have reported observations of low $\mathrm{O}_{3}$ in tropospheric volcanic plumes (Oppenheimer et al., 2010; Vance et al., 2010; Schumann et al., 2011) and have speculated that their observations were a consequence of in-plume bromine chemistry, although supporting measurements of BrO or other reactive halogens were not included. Boichu et al. (2011) presented a study where $\mathrm{BrO}$ was identified in the young Mt. Erebus plume (aged 3-7 min) in spectra collected on Dec. 3, 2005, and based on this finding and model results, showed that bromine chemistry could have been responsible for the low in-plume $\mathrm{O}_{3}$ Oppenheimer et al. (2010) observed $26-39 \mathrm{~km}$ downwind (4-6 h plume travel time) during their research flight a week later, on Dec. 10, 2005. However, in another study, Heue et al. (2011) identified BrO in a 1-2 day old plume from Eyjafjallajökull but found no measureable $\mathrm{O}_{3}$ depletion. Further complexity in establishing the links between $\mathrm{O}_{3}$ and bromine chemistry in volcanic plumes was discussed by Carn et al. (2011), who reported $\mathrm{O}_{3}$ deficits of $20-30 \%$ in volcanic plumes from Ecuador and Colombia aged from $\sim 22-48 \mathrm{~h}$ and $\sim 2 \mathrm{~h}$, respectively, but concluded that insufficient knowledge of ambient $\mathrm{O}_{3}$ during the plumes' evolution prevented them from unambiguously attributing the observed anomalies to reactive halogen chemistry.

To further examine the fast halogen-mediated chemical reactions occurring in volcanic plumes, we conducted an airborne and groundbased investigation of the tropospheric plume of Redoubt Volcano, Alaska. The data reported here relate to rapid chemical processes occurring in the plume after volcanic volatiles were released to the atmosphere and aged up to $\sim 2 \mathrm{~h}$ during the daytime. We report new observations of halogen-containing $(\mathrm{F}, \mathrm{Cl}, \mathrm{Br}, \mathrm{I})$ gases collected using filter packs from the rim of the volcano on June 20, 2010 that constrain the composition of the young plume ( $<5$ min old) as well as detailed airborne observations from flights on June 21st and August 19th, 2010 where the chemical evolution of the plume was tracked with an instrumented fixed-wing aircraft. We describe a method for mitigating $\mathrm{SO}_{2}$ interference in ultraviolet (UV) absorption-based $\mathrm{O}_{3}$ measurements and report in situ observations of $\mathrm{O}_{3}$, water vapor, $\mathrm{CO}_{2}, \mathrm{SO}_{2}$, and $\mathrm{H}_{2} \mathrm{~S}$ from both flights plus airborne remote UV spectroscopic observations of $\mathrm{SO}_{2}$ and BrO from the August 19th flight.

Using airborne measurements we first characterize the composition of ambient air entrained into the plume and estimate the degree to which entrainment of air from chemically distinct ambient air layers influences the plume's $\mathrm{O}_{3}$ composition. Next, we quantify the extent and duration of chemical $\mathrm{O}_{3}$ loss in the plume. Finally we compare our measurements with results from a state-of-the-art chemical model of volcanic plume chemistry (PlumeChem, Roberts et al., 2009) tuned to the environmental conditions at Redoubt on June 21 and initialized using the filter pack data from June 20. Our results highlight important aspects of in-plume chemical and dynamic processes and provide insights that will be useful for better understanding $\mathrm{O}_{3}$ anomalies and reactive halogen chemistry in volcanic plumes.

\section{Field setting: Redoubt Volcano}

Redoubt Volcano $\left(60.485^{\circ} \mathrm{N}, 152.744^{\circ} \mathrm{W}, 3108 \mathrm{~m}\right)$ is a glaciated continental arc stratovolcano located in the Cook Inlet of south-central Alaska, approximately $170 \mathrm{~km}$ southwest of Anchorage (Fig. 1). It is one of the most active volcanoes in the Cook Inlet. Historical activity includes eruptions in 1902, 1966-68, 1989-90 (Miller et al., 1998), and most recently in 2009. The eruption of 2009 included at least 19 explosion events from March 22-April 4, 2009 followed by a 3-month period of lava extrusion that lasted until July 2009 and resulted in growth of a $\sim 72 \cdot 10^{6} \mathrm{~m}^{3}$ lava dome within the breached summit crater (Bull and Buurman, 2013; Bull et al., 2013; Diefenbach et al., 2013). Anomalous degassing associated with the 2009 eruption was first measured 5 months prior to eruption, in Oct. 2008, and has persisted at elevated levels compared to typical non-eruptive background values (i.e. $<10$ tonnes day ${ }^{-1} \mathrm{SO}_{2}$; Doukas and McGee, 2007) through at least Aug. 2011 (unpub. data). The overall degassing record of the eruption is well constrained by airborne and satellite observations and is discussed in detail elsewhere (Werner et al., 2012, 2013; Pfeffer et al., 2013; Lopez et al., 2013).

The data reported here were collected late in the eruption sequence and over 440 days after the last explosion. The emissions originated from the passively-degassing lava dome $\left(60.490^{\circ} \mathrm{N}, 152.762^{\circ} \mathrm{W}\right.$, $\sim 2400 \mathrm{~m}$ ) and were transported downwind in the free troposphere at altitudes of $\sim 2500$ to $3000 \mathrm{~m}$ (Fig. 2). While the data reported here do not directly relate to the main explosive or effusive phases of the 


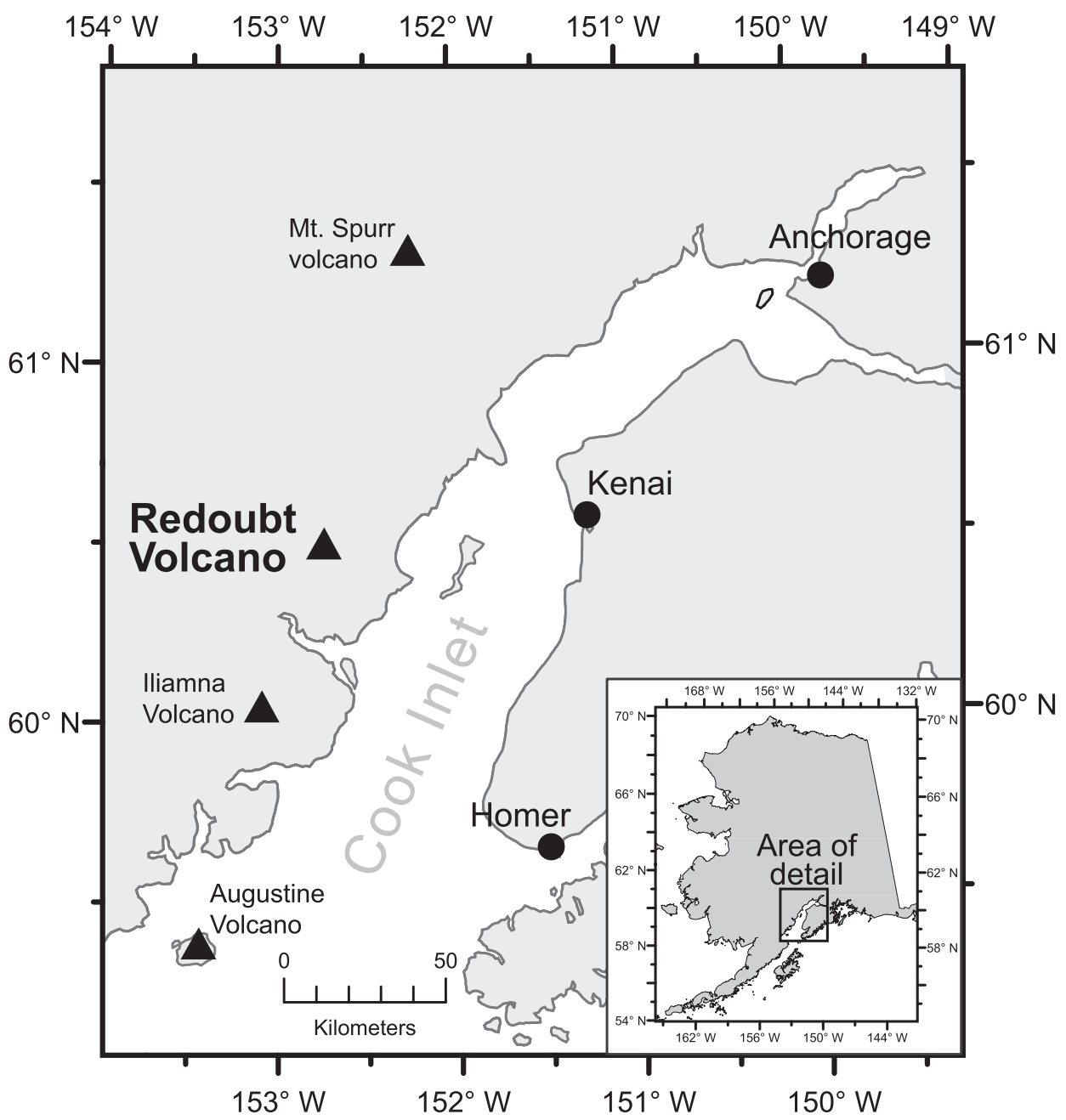

Fig. 1. Location map showing Redoubt Volcano and other volcanoes of Cook Inlet, Alaska. Inset map shows the location of the Cook Inlet in Alaska.

eruption, they do allow investigation of in-plume chemical processes that may be too hazardous to observe during periods of more vigorous volcanic activity. In addition, the data show that passive volcanic degassing can continue to impact the atmosphere long after explosive activity has ceased.

\section{Methods and instruments}

\subsection{Ground-based filter pack sampling}

On June 20th, 2010 we sampled acid gases in the plume using "filter packs" from a sampling site high on the west $\operatorname{rim}\left(60.489^{\circ} \mathrm{N}, 152.779^{\circ}\right.$ W, $2750 \mathrm{~m}$ ) of Redoubt. The site was located approximately $300 \mathrm{~m}$ above and $700 \mathrm{~m}$ west of the lava dome edge (Fig. 2). The purpose of the filter pack sampling was to characterize the composition of the young volcanic plume with respect to halogen $(\mathrm{F}, \mathrm{Cl}, \mathrm{Br}, \mathrm{I})$ and sulfurcontaining acid gases and was accomplished according to the method and procedures described by Aiuppa et al. (2005). The filter packs consisted of four filters assembled in series and attached to an air pump that drew plume air through the assembly at 4 liters per minute (lpm). The first filter blocked aerosol particles and the next three were treated with $1 \mathrm{M} \mathrm{NaHCO}_{3}$ to trap acid gases. Based on visual observations of the plume and the sampling location's close proximity to the lava dome, we estimate the gases we sampled at the crater rim to be $<5$ min old.

Two sets of filter pack samples were collected. One set was exposed for $60 \mathrm{~min}$ and the other for $64 \mathrm{~min}$. In the laboratory, each filter was eluted in $20 \mathrm{ml}$ bi-distillate $\mathrm{H}_{2} \mathrm{O}$. One $10 \mathrm{ml}$ aliquot of each extract was spiked with $\mathrm{H}_{2} \mathrm{O}_{2}$ to oxidize any reduced S present, and then analyzed for $\mathrm{Cl}^{-}$ and $\mathrm{SO}_{4}^{2-}$ by ion chromatography. The remaining $10 \mathrm{ml}$ were preserved by addition of concentrated $\mathrm{NH}_{3}$ until analysis (for dissolved $\mathrm{Br}$ and I) by ICP-MS (Agilent 7500ce). The leachates were also analyzed for $\mathrm{F}^{-}$by ion selective electrode (Aiuppa et al., 2005), which resulted in successful detection in only 2 of the 4 samples. All measurements were carried out at the Istituto Nazionale di Geofisica e Vulcanologia (INGV), Sezione di Palermo, Italy. Typical laboratory uncertainties are approximately $\pm 10 \%$ for $\mathrm{S}, \mathrm{F}, \mathrm{Cl}, \mathrm{Br}$, and $\pm 25 \%$ for I, respectively.

\subsection{Airborne plume sampling strategy}

Our flight paths were designed to intercept the volcanic plume multiple times using two different sampling strategies: "ladder traverses" and "downwind traverses." Ladder traverses were made at approximately the same horizontal distance from the volcano and normal to the wind direction at evenly spaced altitude intervals from the top to the base of the plume in order to sample an in situ vertical plume cross section (e.g. Gerlach et al., 1997; McGee et al., 2001). During downwind traverses, constant-altitude plume transects were made perpendicular to the wind direction at different distances from the volcano with the goal of observing changes in the chemical composition of the plume. Wind speed and direction were determined using the wind circle method (Doukas, 2002) before and after plume sampling. Plume ages were estimated using the downwind distance of each traverse from the lava dome and the observed average wind speed. 

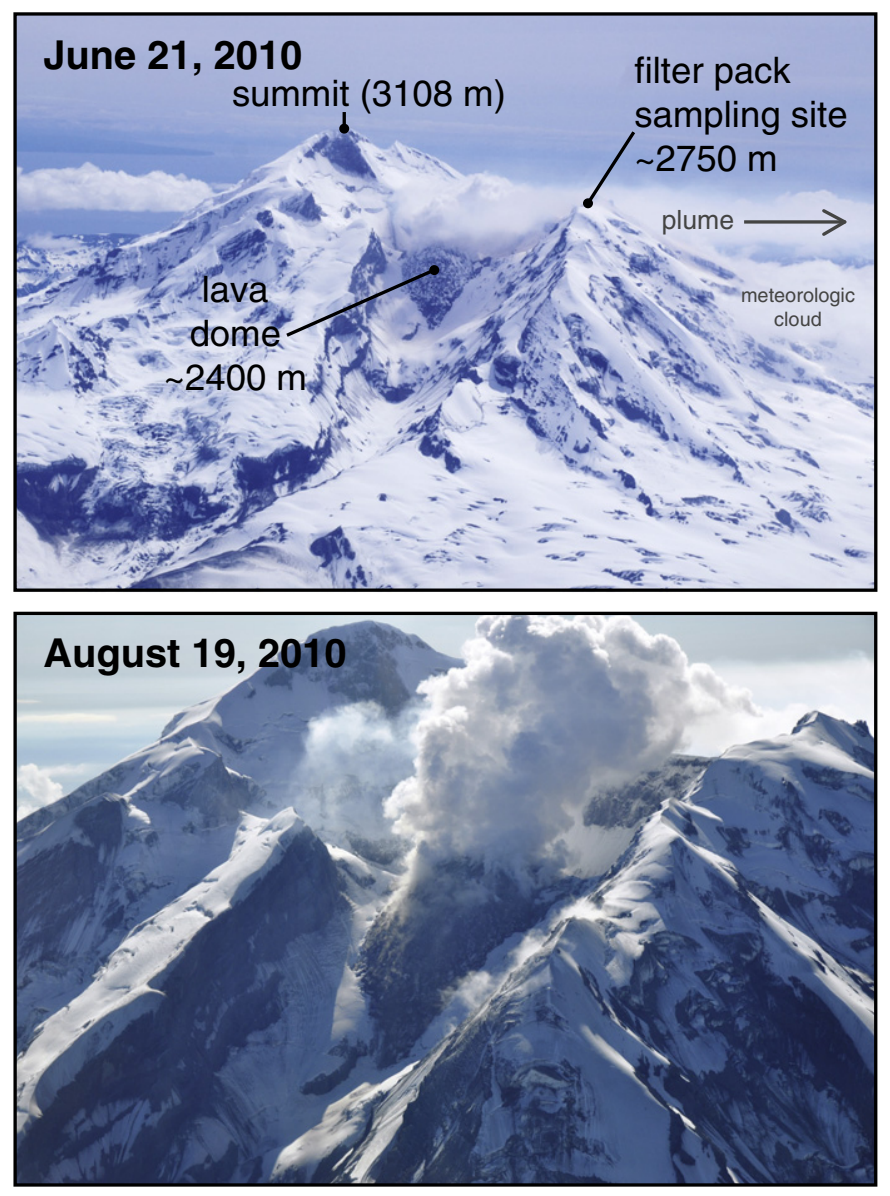

Fig. 2. Photographs showing Redoubt Volcano on June 21 and August 19, 2010.

\subsection{Airborne in situ observations}

Airborne measurements were made from an unpressurized PA-31 Navajo aircraft. The aircraft was equipped to measure in situ concentrations of $\mathrm{O}_{3}, \mathrm{CO}_{2}, \mathrm{SO}_{2}, \mathrm{H}_{2} \mathrm{~S}$, as well as ambient static temperature, static pressure, and the temperature and relative humidity ( $\mathrm{RH}$ ) of air in the sample manifold. Analytical uncertainties for the in situ measurements are summarized in Table 1. A commercial dual-beam UV absorption instrument (2B Technologies, Inc., Model 205) was used to measure $\mathrm{O}_{3}$. Cross-sensitivities of the $\mathrm{O}_{3}$ analyzer to $\mathrm{SO}_{2}$ were mitigated according to the method described briefly in the next section and in more detail in the electronic supplement to this article (Appendix B). $\mathrm{CO}_{2}$ was measured using a commercial nondispersive infrared analyzer (LI-COR, Inc., model LI-7000) modified with pressure and flow controllers and temperature stabilization. Miniature electrochemical sensors were used to measure in situ $\mathrm{SO}_{2}$ (Interscan, Inc., model 4240-1999b) and $\mathrm{H}_{2} \mathrm{~S}$ (Interscan, Inc., model 4170-1999b) gases. Ambient temperature measurements were made with a type-T thermocouple that extended into the free air stream outside the aircraft and was shielded from wind and sun. Pressure measurements were made within the cabin of the unpressurized aircraft and were assumed to be equal to ambient static pressure. The temperature and relative humidity of air in the sample manifold was measured using a Vaisala, Inc. model HMP-50 T/RH probe mounted directly into the sample manifold. Position and altitude were recorded with a GPS receiver. All in situ data were recorded at $1 \mathrm{~Hz}$ except for $\mathrm{O}_{3}$ which had a maximum sampling rate of $0.5 \mathrm{~Hz}$. All data were displayed in real time and logged to a laptop running custom LabVIEW software. The ambient $\mathrm{RH}, \mathrm{H}_{2} \mathrm{O}$ mixing ratio, and potential temperature were calculated during data post-processing.

Air was conveyed to the in situ instruments with a forward-facing ram air inlet located near the front of the aircraft and connected to a stainless steel manifold by $3.5 \mathrm{~m}$ of $0.953 \mathrm{~cm}$ inner diameter (I.D.) CFLEX ${ }^{\circledR}$ tubing. The instruments sampled air from the manifold with

Table 1

Summary of airborne in situ chemical measurements and estimated uncertainties.

\begin{tabular}{|c|c|c|c|c|c|c|}
\hline Measurement & Sample rate $(\mathrm{Hz})$ & Measurement principle & Random uncertainty $(2 \sigma)$ & Systematic bias & calibration accuracy & Units \\
\hline Temperature & 1 & Thermocouple & \pm 0.1 & - & \pm 0.8 & ${ }^{\circ} \mathrm{C}$ \\
\hline Pressure & 1 & Transducer & \pm 0.2 & - & \pm 3 & $\mathrm{hPa}$ \\
\hline Relative humidity & 1 & Capacitance probe & \pm 0.1 & - & $\pm 5 \%$ & $\%$ \\
\hline $\mathrm{H}_{2} \mathrm{O}$ & 1 & Calculated & \pm 0.1 & - & $\pm 5 \%$ & $\mathrm{~g} \mathrm{~kg}^{-1}$ \\
\hline $\mathrm{CO}_{2}$ & 1 & Infrared absorption & \pm 0.3 & - & $\pm 1 \%$ & ppmv \\
\hline $\mathrm{SO}_{2}$ & 1 & Electrochemical & \pm 0.004 & $\leq-10 \%$ & $\pm 5 \%$ & ppmv \\
\hline $\mathrm{H}_{2} \mathrm{~S}$ & 1 & Electrochemical & \pm 0.002 & $\leq-30 \%$ & $\pm 5 \%$ & ppmv \\
\hline $\mathrm{O}_{3}{ }^{\mathrm{a}}$ & 0.5 & UV absorption & \pm 5 & - & $\pm 2 \%$ & ppbv \\
\hline
\end{tabular}

Note: $\mathrm{H}_{2} \mathrm{O} \mathrm{g} \mathrm{kg}{ }^{-1}=\left(\mathrm{H}_{2} \mathrm{O} \mathrm{mmol} \mathrm{mol}{ }^{-1}\right) * 0.622 ; \mathrm{ppmv}=\mu \mathrm{mol} \mathrm{mol}{ }^{-1}$. STP for $\mathrm{H}_{2} \mathrm{O}, \mathrm{SO}_{2}$, and $\mathrm{H}_{2} \mathrm{~S}$ mixing ratio calculations $=25{ }^{\circ} \mathrm{C}$ and $1013.25 \mathrm{hPa}$

a Values given for measurements in clean air. See Section 3.4 for more information. 
short $(<30 \mathrm{~cm}$ ) individual lengths of $0.635 \mathrm{~cm}$ outer diameter (O.D.) polyethylene (Bev-a-line ${ }^{\circledR}$ IV) tubing to minimize instrumental response times. While underway, the flow rate of ram air through the manifold was $\sim 25 \mathrm{lpm}$, approximately 5 times greater than instrumental demand. Excess ram air was exhausted to the outside via a port located near the rear of the aircraft. The manifold was connected to the outlet port by a 1 meter length of $0.953 \mathrm{~cm}$ I.D. Tygon ${ }^{\circledR}$ tubing. Assuming plug flow, the residence time of sample air in the aircraft was $<100 \mathrm{~ms}$. More detailed descriptions of the airborne instrumentation as well as the accuracy and precision of the measurements are given in the electronic supplement to this article (Appendix A).

\subsection{Mitigating $\mathrm{SO}_{2}$ interference in UV-absorption based ozone measurements}

Use of an interference-free technique to measure $\mathrm{O}_{3}$, such as chemiluminescence, would be preferable for making observations in volcanic plumes but unfortunately is not always practical. We acknowledge that the method we describe below has significant uncertainty but it has the advantage of using more common, inexpensive, and portable $\mathrm{O}_{3}$ and $\mathrm{SO}_{2}$ sensors to obtain information about $\mathrm{O}_{3}$ in $\mathrm{SO}_{2}$-rich volcanic plumes.

The $\mathrm{O}_{3}$ molecule's strong $254 \mathrm{~nm}$ absorption band allows atmospheric $\mathrm{O}_{3}$ concentrations to be measured through UV absorption spectroscopy. Under normal atmospheric conditions there are few interfering gases in this wavelength region. However, even in dilute volcanic plumes, concentrations of $\mathrm{H}_{2} \mathrm{O}$ and $\mathrm{CO}_{2}$ can be elevated and concentrations of $\mathrm{SO}_{2}$ and $\mathrm{H}_{2} \mathrm{~S}$ can be several orders of magnitude greater than in typical ambient air. Of these major constituents of volcanic gases, only $\mathrm{SO}_{2}$ strongly absorbs UV radiation of this wavelength such that it can cause significant interference in $\mathrm{O}_{3}$ measurements. Aside from $\mathrm{SO}_{2}$, other potential interferences include mercury gas and liquid water, both of which strongly absorb UV light. Observations of gaseous elemental mercury in the plume on August 19, 2010 suggest that it was not present at high enough concentrations to interfere with the $\mathrm{O}_{3}$ measurements (Kelly et al., in prep.), and sample air was dried to prevent water condensation in the optical cells.

UV-absorption $\mathrm{O}_{3}$ monitors operate by comparing the intensity of light that passes through ozone-scrubbed $\left(I_{0}\right)$ and unscrubbed air $(I)$ and a Beer-Lambert calculation. Some instruments feature a single optical cell (e.g. 2BTech Model 202) where ozone-scrubbed and unscrubbed air is alternately drawn into the cell every few seconds to derive the $\mathrm{O}_{3}$ concentration. Other instruments feature dual optical cells (e.g. the 2BTech Model 205 used in this study) where $I_{\mathrm{o}}$ and $I$ are determined simultaneously by porting ozone-scrubbed air into one cell and unscrubbed air into the other. Both single and dual-beam instruments are susceptible to interference from $\mathrm{SO}_{2}$ because the chemical scrubber used to remove $\mathrm{O}_{3}$ also removes $\mathrm{SO}_{2}$ from the reference air used to determine $I_{0}$. Therefore the scrubbed air will be free of $\mathrm{O}_{3}$ and $\mathrm{SO}_{2}$ and the unscrubbed air will contain both species. As a result, the presence of $\mathrm{SO}_{2}$ will introduce interference into UV-based $\mathrm{O}_{3}$ measurements regardless of whether a single or dual-cell UV absorption $\mathrm{O}_{3}$ instrument is used.
$\mathrm{O}_{3}$ absorbs $254 \mathrm{~nm}$ light about two orders of magnitude more strongly than $\mathrm{SO}_{2}$ but in volcanic plumes $\mathrm{SO}_{2}$ can be several orders of magnitude more abundant than $\mathrm{O}_{3}$. Thus, depending on the levels of $\mathrm{SO}_{2}$ encountered, this interference may need to be mitigated in order to retrieve accurate $\mathrm{O}_{3}$ measurements. According to laboratory measurements of $\mathrm{O}_{3}$ (Sander et al., 2006) and $\mathrm{SO}_{2}$ (Vandaele et al., 2009; Bogumil et al., 2003; Rufus et al., 2003; Wu et al., 2000) absorption cross-sections for temperatures between 293 and $298 \mathrm{~K}, 1$ ppmv of $\mathrm{SO}_{2}$ should result in interference of about 11.5-13.6 ppbv $\mathrm{O}_{3}$ in UVabsorption measurements made at $253.7 \mathrm{~nm}$. We performed laboratory tests to verify our $\mathrm{O}_{3}$ sensor's response to $\mathrm{SO}_{2}$ and found it to be positive and linear such that every $1 \mathrm{ppmv} \mathrm{SO}_{2}$ resulted in positive interference of $11.5 \pm 1 \mathrm{ppbv} \mathrm{O}_{3}$, which is within the theoretical range. Based on our findings, we corrected the $\mathrm{O}_{3}$ data for $\mathrm{SO}_{2}$ interference using simultaneous and independent $\mathrm{SO}_{2}$ measurements (described in Section 3.3), the empirically-derived correction factor, and the following relationship:

$$
\left[\mathrm{O}_{3(\text { ppbv }, \text { corrected })}\right]=\left[\mathrm{O}_{3(\mathrm{ppbv}, \mathrm{raw})}\right]-11.5\left[\mathrm{SO}_{2(\mathrm{ppmv})}\right] \text {. }
$$

We note that the empirically-determined response of a UVabsorption $\mathrm{O}_{3}$ sensor to $\mathrm{SO}_{2}$ will vary between instruments due to uncertainty in their respective standards and the efficiency of the scrubber and should be established on an individual basis. The most important point is that the $\mathrm{O}_{3}$ instrument's response to $\mathrm{SO}_{2}$ should be established with the same standard used to calibrate the $\mathrm{SO}_{2}$ instrument to ensure that the measurements are internally consistent.

This approach to mitigating $\mathrm{SO}_{2}$ interference is relatively straightforward in principle but has several potential weaknesses that must be considered in practice. First, the method relies on both instruments being well calibrated, stable, and that the response of both sensors to $\mathrm{SO}_{2}$ is internally consistent. Frequent in-flight calibration is one way to ensure this requirement is met. Second, the instrumental response times must be similar. In-flight and laboratory testing shows that the time constant for the $\mathrm{SO}_{2}$ sensor response was about $2 \mathrm{~s}$ and for the $\mathrm{O}_{3}$ instrument was about $1 \mathrm{~s}$, respectively. Since the $\mathrm{SO}_{2}$ response was slightly slower, large and rapid changes in $\mathrm{SO}_{2}$ could cause mismatches between the sensors and lead to inaccuracy in the corrected $\mathrm{O}_{3}$ values. For the data presented herein, the rate and magnitude of $\mathrm{SO}_{2}$ variations lead to insignificant mismatches between the sensors and can be neglected (further details are provided in the electronic supplement to this article, Appendix B), but this assumption may not always be true and must be evaluated carefully. Third, $\mathrm{SO}_{2}$ is a sticky gas so manifold flow rates must be high and sample line lengths must be as short as possible (as described in Section 3.3) to minimize effects from adsorption and desorption that could lead to mismatches between the instruments.

Correcting the $\mathrm{O}_{3}$ measurements for $\mathrm{SO}_{2}$ interference increases the uncertainty of the corrected $\mathrm{O}_{3}$ mixing ratios due to additional uncertainties in the correction factor $(11.5 \pm 1$, or about $\pm 10 \%$ relative) and in the $\mathrm{SO}_{2}$ measurement $( \pm 10 \%)$. Thus we estimate the total uncertainty of the $\mathrm{SO}_{2}$ correction term in Eq. (1) is $\pm 20 \%$, or, for example, an additional \pm 2 ppbv of uncertainty in the corrected $\mathrm{O}_{3}$ mixing ratio per 1 ppmv of collocated $\mathrm{SO}_{2}$.

Table 2

Mean gas-phase concentrations of halogens and sulfur in Redoubt Volcano's plume measured using filter packs on June $20,2010$.

\begin{tabular}{|c|c|c|c|c|c|}
\hline & $\mathrm{F}$ & $\mathrm{Cl}$ & $\mathrm{Br}$ & I & $\mathrm{S}$ \\
\hline Concentration $\left(\mu \mathrm{g} \mathrm{m}^{-3}\right)$ & $15(3)$ & $131(22)$ & $1.90(0.08)$ & $0.10(0.01)$ & $187(30)$ \\
\hline Mixing ratio (ppbv) & $25(5)$ & 115 (19) & $0.75(0.03)$ & $0.025(0.002)$ & $182(30)$ \\
\hline Molar ratio (X/S) & $0.14(0.04)$ & $0.63(0.15)$ & $0.0041(0.0007)$ & $0.00014(0.00003)$ & - \\
\hline
\end{tabular}

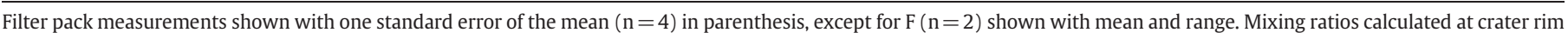
conditions $\left(\mathrm{T}=0{ }^{\circ} \mathrm{C}\right.$ and $\left.\mathrm{P}=730 \mathrm{hPa}\right) . \mathrm{X}=\mathrm{F}, \mathrm{Cl}, \mathrm{Br}, \mathrm{I}$. 


\subsection{Airborne remote spectroscopic observations of $\mathrm{SO}_{2}$ and $\mathrm{BrO}$}

Remote measurements of $\mathrm{SO}_{2}$ column density were made using a correlation spectrometer (COSPEC V; Stoiber et al., 1983) on both flights, and a FLYSPEC-type miniature passive UV spectrometer (Ocean optics USB2000; Horton et al., 2006) was also utilized on August 19. The COSPEC was mounted onboard the aircraft with a zenith-looking periscope and data were logged to the laptop at $1 \mathrm{~Hz}$ sampling rate. On August 19th the FLYSPEC instrument was mounted onboard the aircraft with an additional dedicated zenith-looking periscope and data were logged to a dedicated laptop computer. Retrievals for $\mathrm{SO}_{2}$ and $\mathrm{BrO}$ column densities were obtained using the differential optical absorption spectroscopy (DOAS) methodology (see e.g. Platt and Stutz, 2008). Detailed information describing the $\mathrm{SO}_{2}$ and $\mathrm{BrO}$ retrieval procedures is included in an electronic supplement to this article (Appendix C).

\section{Results}

\subsection{June 20,2010 , filter packs}

The base-treated filter packs yielded small but quantifiable amounts of $\mathrm{F}, \mathrm{Cl}, \mathrm{Br}, \mathrm{I}$, and $\mathrm{S}$ (Table 2). The results show that $\mathrm{Cl}$ was the most abundant halogen we measured, and that $\mathrm{F}, \mathrm{Br}$, and I were about 1, 2, and 3 orders of magnitude less abundant, respectively. Average concentrations were low but all the species were elevated by at least 1 order of magnitude above average ambient tropospheric levels (e.g. $\mathrm{F}=1.8 \mathrm{ppbv}, \mathrm{Cl}=3.6 \mathrm{ppbv}, \mathrm{Br}=0.016 \mathrm{ppbv}, \mathrm{I}=0.002 \mathrm{ppbv}$; Warneck, 2000). We note that our derived average $\mathrm{Cl}$ concentrations were only a factor $\sim 2$ larger than the technique detection limit $\left(\sim 60 \mu \mathrm{g} \mathrm{m}{ }^{3}\right)$, and that I concentrations were only a factor $\sim 2-10$ higher than is found in normal background atmosphere if organic species are considered (see online supplement to Simpson et al., 2007, and references therein). Therefore, it is possible that the I measurements may contain significant non-volcanic contributions and for this reason should be viewed only as a first-order (semi-quantitative) estimate of volcanic emissions. Even so, based on the positive variation between $\mathrm{S}$ and $\mathrm{Cl}\left(\mathrm{r}^{2}=0.89 ; \mathrm{n}=4\right)$, we are confident that volcanic gases were captured by our measurements.

The mean molar $\mathrm{F} / \mathrm{S}\left(1.4 \cdot 10^{-1}\right), \mathrm{Cl} / \mathrm{S}\left(6.3 \cdot 10^{-1}\right)$, and $\mathrm{Br} / \mathrm{S}$ ratios $\left(4.1 \cdot 10^{-3}\right)$ from the filters all fall within the range expected for Arc volcanoes (Gerlach, 2004; Pyle and Mather, 2009). The I/S ratio $\left(1.4 \cdot 10^{-4}\right)$ is higher than those reported elsewhere (molar $\mathrm{I} / \mathrm{S}=4.0 \cdot 10^{-6}$ to 5.5 $\cdot 10^{-5}$; Aiuppa et al., 2005; Witt et al., 2008; Sawyer et al., 2011) but the significance of this result is unclear due to the large uncertainty of this measurement and because very little data on I degassing from volcanoes have been reported. The $\mathrm{Cl} / \mathrm{S}$ and $\mathrm{Br} / \mathrm{S}$ ratios were higher than the molar "Arc Mean" $\mathrm{HCl} / \mathrm{SO}_{2}\left(5.3 \cdot 10^{-1}\right)$ and $\mathrm{HBr} / \mathrm{SO}_{2}\left(1.2 \cdot 10^{-3}\right)$ ratios and about an order of magnitude less than the "Arc $\mathrm{Max}$ " $\mathrm{HCl} / \mathrm{SO}_{2}(4.8)$ and $\mathrm{HBr} / \mathrm{SO}_{2}\left(3.3 \cdot 10^{-2}\right)$ calculated by Gerlach (2004) for hightemperature samples. The mean molar $\mathrm{Br} / \mathrm{Cl}$ ratio $\left(6.5 \cdot 10^{-3}\right)$ is higher by about a factor of three than the $\mathrm{Arc} \mathrm{Mean} \mathrm{Br} / \mathrm{Cl}$ ratio $\left(2.2 \cdot 10^{-3}\right)$ and is near the top of the range for high-temperature condensate samples from arc volcanoes $\left(4.7 \cdot 10^{-4}-7.1 \cdot 10^{-3}\right.$; Gerlach, 2004).

One drawback of the filter pack method is that it is non-selective and for this reason we cannot evaluate the speciation of the gases trapped on the filters. Plume chemistry models propose that the speciation of halogen gases can undergo large and rapid changes after emission (Bobrowski et al., 2007; Roberts et al., 2009; von Glasow, 2010). Therefore, even though the gases we sampled were young

\section{June 2010}
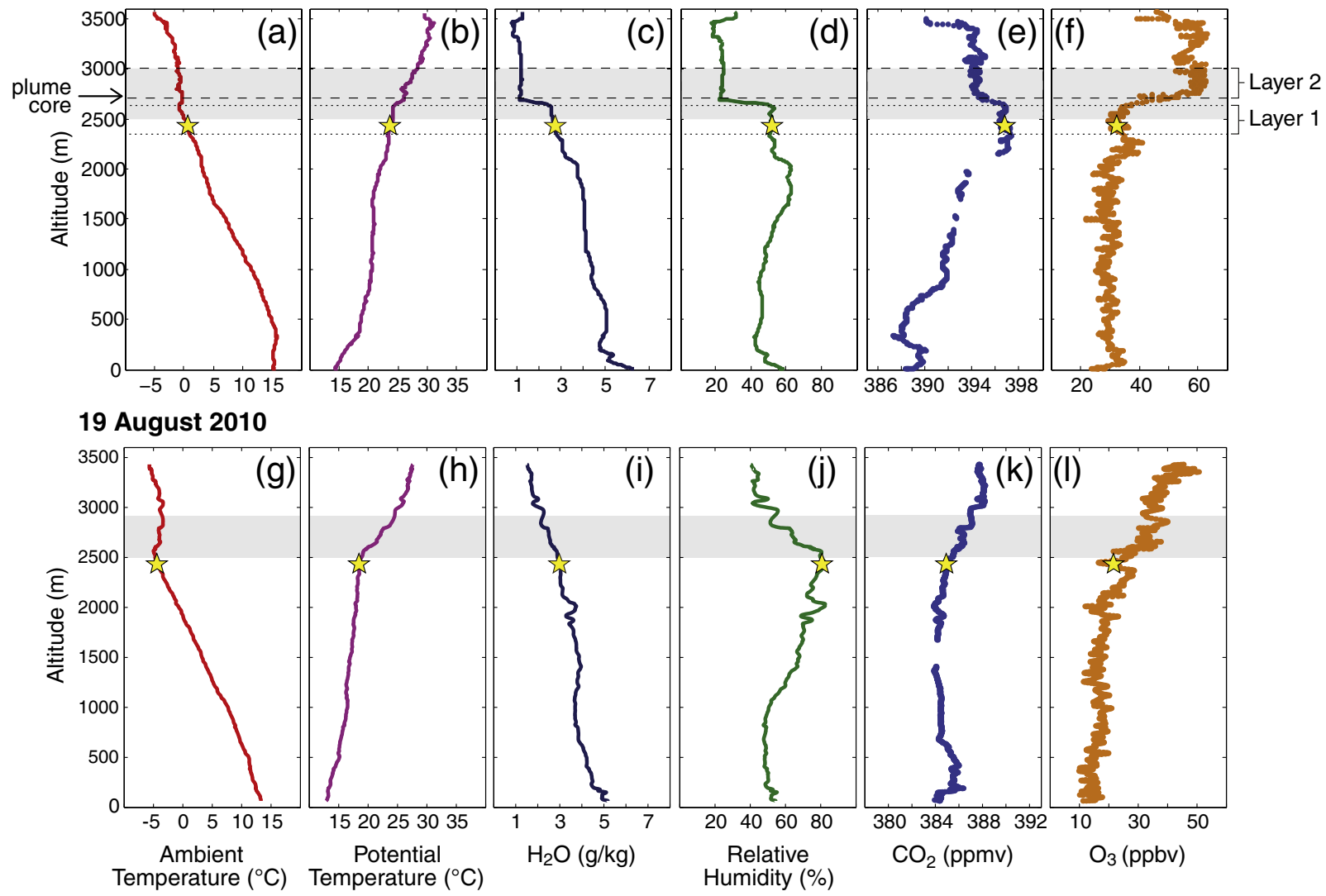

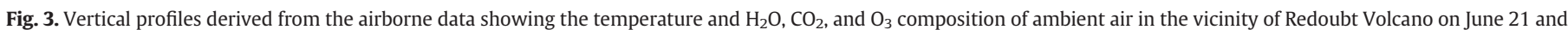

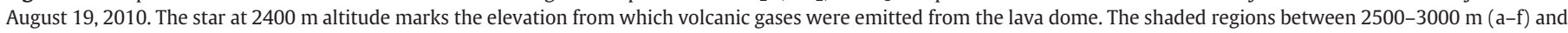

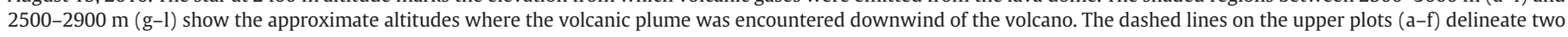
layers in the stratified troposphere (Layer 1 and Layer 2) that were defined based on their contrasting compositions. 


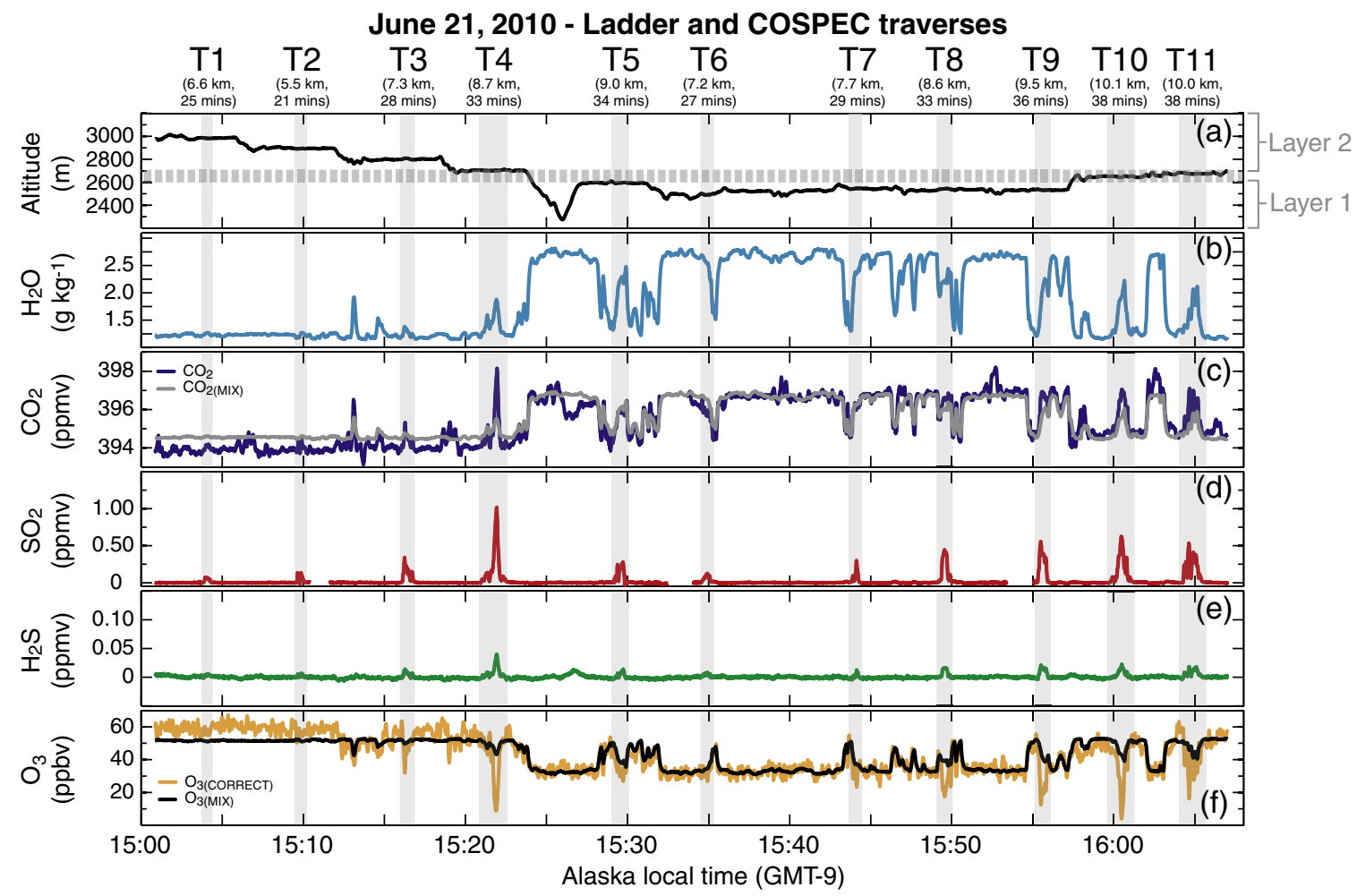

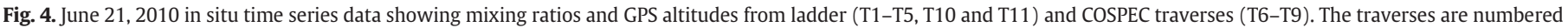

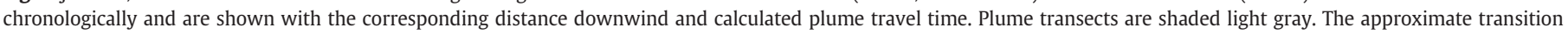

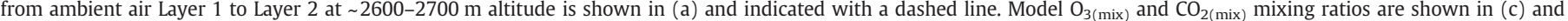
(f). See sections 5.1 and 5.2 for details.

$(<5 \mathrm{~min})$ they may not adequately represent the true initial composition of the plume. Nevertheless, the halogen to sulfur ratios we obtained are reasonable when compared to high-temperature samples and represent the best available estimate of the initial composition of the plume with respect to halogen-containing acid gases.

\subsection{June 21, 2010 airborne results}

The objective of the June 21 flight was to obtain detailed in situ observations of plume compositions, especially $\mathrm{O}_{3}$. We utilized both ladder and downwind traverses to sample the plume composition. Weather during the flight was mostly clear with scattered cumulus and much higher and intermittent cirrostratus clouds. The cumulus clouds prevented us from flying completely beneath the plume for COSPEC observations but otherwise were not problematic. The average and range of the wind speed measurements was $4.4 \pm 0.9 \mathrm{~m} \mathrm{~s}^{-1}$ $(n=5)$. The wind was from the northeast $\left(50^{\circ}\right)$ and shifted east slightly $\left(70^{\circ}\right)$ by the end of sampling.

Vertical profiles of ambient air composition (Fig. 3a-f) show that the lower troposphere was stratified and heterogeneous, especially between the altitudes from which volcanic gases were emitted ( $2400 \mathrm{~m}$; marked by the star) and sampled downwind (2500$3000 \mathrm{~m}$; shaded region). A small inversion at $2600 \mathrm{~m}$ and a mixing zone between $\sim 2600$ and $2700 \mathrm{~m}$ separated two layers with significantly different $\mathrm{H}_{2} \mathrm{O}, \mathrm{CO}_{2}$, and $\mathrm{O}_{3}$ compositions. Layer 1 ( 2400$2600 \mathrm{~m}$ altitude) had an average $\mathrm{H}_{2} \mathrm{O}$ mixing ratio of about $2.7 \mathrm{~g} \mathrm{~kg}^{-1}, \mathrm{CO}_{2}$ of $397 \mathrm{ppmv}$, and an $\mathrm{O}_{3}$ mixing ratio of $33 \mathrm{ppbv}$. In contrast, the overlying Layer 2 at $\sim 2700-3000 \mathrm{~m}$ altitude had lower average $\mathrm{H}_{2} \mathrm{O}\left(1.2 \mathrm{~g} \mathrm{~kg}^{-1}\right.$ ) and $\mathrm{CO}_{2}$ mixing ratios (394 ppmv), and a much higher $\mathrm{O}_{3}$ mixing ratio (57 ppbv).

We made 11 traverses between 15:04 and 16:05 AKDT from 3000 to $2500 \mathrm{~m}$ altitude in order to sample an in situ vertical cross section of the plume (ladder traverses 1-6), perform remote COSPEC measurements (traverses 6-9), and resample the plume core (traverses 10 and 11 ) located at $\sim 2700 \mathrm{~m}$ altitude. The measurement results are shown as time series plots in Fig. 4 and pertinent data are summarized in Table 3. Traverses were made at 5.5 to $10.1 \mathrm{~km}$ distance from the lava dome and have corresponding plume age estimates ranging from 21 to $38 \mathrm{~min}$.

The presence of $\mathrm{SO}_{2}$ and $\mathrm{H}_{2} \mathrm{~S}$ can be used as indicators of volcanic gas due to their comparatively low levels in ambient air (e.g. McGee et al., 2001). $\mathrm{SO}_{2}$ comprised about $96 \%$ (molar) of total gaseous sulfur ( $\mathrm{S}_{\text {total }}=\mathrm{SO}_{2}+\mathrm{H}_{2} \mathrm{~S}$ ) and is assumed herein to be a zero-background conservative plume tracer. While $\mathrm{SO}_{2}$ is not strictly conserved, this assumption is justified given the short experimental timescale of the present study $(<2 \mathrm{~h})$. The highest concentrations were encountered during traverse 4 at $2700 \mathrm{~m}$ altitude, with maximum mixing ratios of $1.02 \pm 0.10$ ppmv and $0.04 \pm 0.01$ ppmv for $\mathrm{SO}_{2}$ and $\mathrm{H}_{2} \mathrm{~S}$, respectively. $\mathrm{CO}_{2}$ was up to $4.0 \pm 0.3$ ppmv above background, and a large $\mathrm{O}_{3}$ depletion was also observed during this traverse. The minimum $\mathrm{O}_{3}$ mixing ratio observed in the plume was $5 \pm 6$ ppbv (traverse 10 ), or approximately $90 \%$ below the background value. In general, the largest $\mathrm{O}_{3}$ deficits were observed near the plume core and were well correlated with volcanic gases. COSPEC observations indicated an average $\mathrm{SO}_{2}$ emission rate of $\sim 370$ tonnes day ${ }^{-1}$ ( $\mathrm{t} / \mathrm{d}$; Werner et al., 2013) although this must be considered a minimum estimate because the clouds prevented flying completely beneath the plume and volcanic gas was observed by the in situ instrumentation during each COSPEC traverse. Unfortunately we did not have a FLYSPEC onboard during this flight for $\mathrm{BrO}$ retrievals.

Following the ladder traverses we made 5 in situ downwind traverses (12-16, numbered in order of increasing downwind distance) to characterize the chemical evolution of the plume (Fig. 5, Table 3). The traverses were made between 16:08 and 16:27 AKDT and from 2.4 to $27.8 \mathrm{~km}$ downwind (9 to $105 \mathrm{~min}$ plume travel time) approximately at the altitude of the vertical plume core $(\sim 2700 \mathrm{~m})$. The $\mathrm{SO}_{2}$ 
Table 3

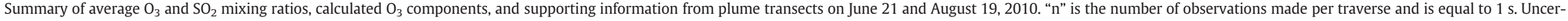
tainties are given in parenthesis and represent one standard error of the mean.

\begin{tabular}{|c|c|c|c|c|c|c|c|c|c|c|c|c|}
\hline Traverse \# & Traverse type & Time & Altitude & Distance downwind & Plume age & $\mathrm{n}$ & Plume width & Temperature & Pressure & Relative humidity & $\mathrm{SO}_{2}$ & Crosswind integrated $\mathrm{SO}_{2}$ \\
\hline \multicolumn{13}{|c|}{$\begin{array}{l}\text { Traverses are numbered chronologically } \\
\text { except for downwind traverses, which } \\
\text { are numbered based on distance from } \\
\text { the volcano }\end{array}$} \\
\hline \multicolumn{13}{|c|}{ June 21, 2010} \\
\hline 1 & In situ/ladder & 15:04 & 2980 & 6.6 & 25 & 24 & 2.2 & -0.7 & 704 & 24 & 0.05 & 110 \\
\hline 2 & In situ/ladder & 15:09 & 2890 & 5.5 & 21 & 25 & 2.3 & -0.3 & 713 & 23 & 0.06 & 140 \\
\hline 3 & In situ/ladder & 15:16 & 2800 & 7.3 & 28 & 41 & 3.7 & -0.1 & 721 & 24 & 0.14 & 510 \\
\hline 4 & In situ/ladder & $15: 21$ & 2700 & 8.7 & 33 & 91 & 8.2 & 0.1 & 728 & 27 & 0.21 & 1760 \\
\hline 5 & In situ/ladder & $15: 29$ & 2590 & 9.0 & 34 & 39 & 3.5 & -0.2 & 739 & 41 & 0.16 & 550 \\
\hline 6 & Remote/COSPEC & $15: 34$ & 2490 & 7.2 & 27 & 42 & 3.6 & 0.2 & 748 & 45 & 0.06 & 220 \\
\hline 7 & Remote/COSPEC & $15: 44$ & 2540 & 7.7 & 29 & 29 & 2.6 & -0.1 & 744 & 42 & 0.10 & 260 \\
\hline 8 & Remote/COSPEC & $15: 49$ & 2540 & 8.6 & 33 & 59 & 5.0 & 0.1 & 745 & 40 & 0.16 & 790 \\
\hline 9 & Remote/COSPEC & $15: 55$ & 2530 & 9.5 & 36 & 90 & 3.2 & 0.4 & 748 & 37 & 0.32 & 1020 \\
\hline 10 & In situ/T4 repeat & $16: 00$ & 2650 & 10.1 & 38 & 90 & 6.8 & -0.3 & 736 & 31 & 0.19 & 1300 \\
\hline 11 & In situ/T4 repeat & 16:04 & 2670 & 10.0 & 38 & 70 & 6.2 & -0.4 & 733 & 32 & 0.22 & 1360 \\
\hline 13 & In situ/downwind & $16: 08$ & 2680 & 5.1 & 19 & 58 & 4.7 & -0.3 & 732 & 36 & 0.41 & 1900 \\
\hline 12 & In situ/downwind & 16:11 & 2590 & 2.4 & 9 & 38 & 3.5 & -0.5 & 740 & 54 & 0.63 & 2210 \\
\hline 14 & In situ/downwind & $16: 15$ & 2730 & 13.1 & 50 & 103 & 8.9 & -0.6 & 728 & 31 & 0.20 & 1760 \\
\hline 15 & In situ/downwind & $16: 22$ & 2750 & 20.6 & 78 & 123 & 10.8 & -0.8 & 725 & 29 & 0.09 & 950 \\
\hline 16 & In situ/downwind & $16: 27$ & 2750 & 27.8 & 105 & 253 & 18.9 & -1.1 & 724 & 34 & 0.04 & 790 \\
\hline \multicolumn{13}{|c|}{ August 19, 2010} \\
\hline 2 & In situ/downwind & $12: 13$ & 2600 & 5.3 & 19 & 51 & 4.6 & -0.4 & 737 & 61 & 0.71 & 3270 \\
\hline 1 & In situ/downwind & $12: 17$ & 2610 & 5.1 & 18 & 67 & 5.7 & -0.4 & 736 & 60 & 0.46 & 2620 \\
\hline 13 & In situ/downwind & $13: 27$ & 2800 & 10.2 & 36 & 16 & 1.3 & -0.1 & 718 & 51 & 0.12 & 150 \\
\hline 12 & In situ/downwind & 13:33 & 2830 & 7.8 & 28 & 25 & 2.2 & 0.0 & 715 & 47 & 0.27 & 590 \\
\hline 15 & In situ/downwind & 13:40 & 2740 & 18.3 & 65 & 99 & 9.0 & -0.3 & 722 & 55 & 0.05 & 410 \\
\hline 14 & In situ/downwind & 13:46 & 2530 & 17.9 & 63 & 79 & 6.7 & -0.6 & 741 & 60 & 0.09 & 600 \\
\hline
\end{tabular}




\begin{tabular}{|c|c|c|c|c|c|c|c|c|c|}
\hline \multirow{3}{*}{$\begin{array}{l}\frac{\mathrm{O}_{3(\mathrm{bg})}}{\text { Average } \mathrm{O}_{3} \text { in }} \\
\text { background } \\
\text { ambient air } \\
\text { (ppbv) }\end{array}$} & \multirow{3}{*}{$\begin{array}{l}\mathrm{O}_{3 \text { (raw) }} \\
\text { Average indicated } \\
\text { in-plume } \mathrm{O}_{3} \text { not } \\
\text { corrected for } \mathrm{SO}_{2} \\
\text { interference } \\
\text { (ppbv) }\end{array}$} & \multirow{3}{*}{$\begin{array}{l}\mathrm{O}_{3 \text { (correct) }} \\
\text { Average in-plume } \\
\mathrm{O}_{3} \text { corrected for } \\
\mathrm{SO}_{2} \text { interference } \\
\text { (ppbv) }\end{array}$} & \multirow{3}{*}{$\begin{array}{l}\mathrm{O}_{3(\mathrm{mix})} \\
\text { Expected in-plume } \mathrm{O}_{3} \\
\text { due to entrainment and } \\
\text { mixing of heterogeneous } \\
\text { ambient air into plume } \\
\text { (ppbv) }\end{array}$} & \multirow{2}{*}{\multicolumn{2}{|c|}{ 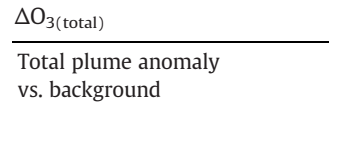 }} & \multirow{2}{*}{\multicolumn{2}{|c|}{$\begin{array}{l}\Delta \mathrm{O}_{3(\mathrm{mix})} \\
\text { Plume anomaly attributed } \\
\text { to entrainment and mixing } \\
\text { of heterogeneous ambient air } \\
\text { into the plume }\end{array}$}} & \multirow{2}{*}{\multicolumn{2}{|c|}{$\begin{array}{l}\Delta \mathrm{O}_{3 \text { (chem) }} \\
\text { Plume anomaly attributed } \\
\text { to in-plume chemistry }\end{array}$}} \\
\hline & & & & & & & & & \\
\hline & & & & (ppbv) & $\mathrm{p}$-value & (ppbv) & $\mathrm{p}$-value & (ppbv) & $\mathrm{p}$-value \\
\hline $57.8(1.0)$ & $57.6(1.0)$ & $57.0(1.1)$ & $58.2(1.0)$ & $-0.8(2.1)$ & 0.70 & $0.4(2.0)$ & 0.83 & $-1.2(2.1)$ & 0.55 \\
\hline $58.2(1.0)$ & $56.0(1.0)$ & $55.3(1.1)$ & $56.6(1.0)$ & $-2.9(2.1)$ & 0.17 & $-1.6(2.0)$ & 0.42 & $-1.3(2.1)$ & 0.54 \\
\hline $56.1(1.0)$ & $48.6(1.0)$ & 47.0 & $55.0(1.0)$ & $-9.1(2.3)$ & $<0.01$ & $-1.1(2.0)$ & 0.60 & $-8.0(2.3)$ & $<0.01$ \\
\hline $51.3(1.0)$ & $44.2(1.5)$ & $41.8(2.0)$ & $48.8(1.0)$ & $-9.5(3.0)$ & $<0.01$ & $-2.5(2.0)$ & 0.21 & $-7.0(3.0)$ & 0.02 \\
\hline $44.5(1.0)$ & $35.4(1.0)$ & $33.6(1.4)$ & $34.5(1.0)$ & $-10.9(2.4)$ & $<0.01$ & $-10.0(2.0)$ & $<0.01$ & $-0.9(2.4)$ & 0.70 \\
\hline $32.7(1.0)$ & $35.7(1.0)$ & $35.0(1.1)$ & $36.0(1.0)$ & $2.4(2.1)$ & 0.25 & $3.4(2.0)$ & 0.09 & $-1.0(2.1)$ & 0.62 \\
\hline $42.4(1.0)$ & $35.1(1.3)$ & $33.9(1.5)$ & $38.6(1.0)$ & $-8.5(2.5)$ & $<0.01$ & $-3.8(2.0)$ & 0.06 & $-4.7(2.5)$ & 0.06 \\
\hline $45.6(1.0)$ & $34.2(1.3)$ & $32.4(1.7)$ & $40.6(1.0)$ & $-13.2(2.7)$ & $<0.01$ & $-5.0(2.0)$ & 0.01 & $-8.2(2.7)$ & $<0.01$ \\
\hline $44.4(1.0)$ & $30.0(1.0)$ & $26.3(1.7)$ & $42.6(1.0)$ & $-18.1(2.7)$ & $<0.01$ & $-1.7(2.0)$ & 0.39 & $-16.3(2.7)$ & $<0.01$ \\
\hline $51.1(1.0)$ & $39.3(1.5)$ & $37.1(1.9)$ & $45.1(1.0)$ & $-14.0(2.9)$ & $<0.01$ & $-5.9(2.0)$ & $<0.01$ & $-8.0(2.9)$ & 0.01 \\
\hline $54.2(1.0)$ & $40.5(1.1)$ & $38.0(1.6)$ & $46.4(1.0)$ & $-16.2(2.6)$ & $<0.01$ & $-7.8(2.0)$ & $<0.01$ & $-8.4(2.6)$ & $<0.01$ \\
\hline $52.9(1.0)$ & $34.3(1.7)$ & $29.7(2.6)$ & $41.8(1.0)$ & $-23.2(3.6)$ & $<0.01$ & $-11.1(2.0)$ & $<0.01$ & -12.1 (3.6) & $<0.01$ \\
\hline $39.4(1.0)$ & $35.6(1.3)$ & $28.4(2.8)$ & $32.5(1.0)$ & -11.0 & $<0.01$ & $-6.9(2.0)$ & $<0.01$ & $-4.1(3.8)$ & 0.29 \\
\hline $52.8(1.0)$ & $39.5(1.0)$ & $37.2(1.5)$ & $47.7(1.0)$ & $-15.6(2.5)$ & $<0.01$ & $-5.1(2.0)$ & 0.01 & $-10.5(2.5)$ & $<0.01$ \\
\hline $54.6(1.0)$ & $45.1(1.0)$ & $44.0(1.2)$ & $49.1(1.0)$ & $-10.6(2.2)$ & $<0.01$ & $-5.5(2.0)$ & 0.01 & $-5.1(2.2)$ & 0.02 \\
\hline $54.4(1.0)$ & $46.3(1.0)$ & $45.8(1.1)$ & $46.8(1.0)$ & $-8.6(2.1)$ & $<0.01$ & $-7.6(2.0)$ & $<0.01$ & $-1.0(2.1)$ & 0.65 \\
\hline $30.0(1.0)$ & $32.4(1.0)$ & $24.2(2.6)$ & $30.1(1.0)$ & $-5.8(3.6)$ & 0.11 & $0.1(2.0)$ & 0.94 & $-5.9(3.6)$ & 0.10 \\
\hline $31.0(1.0)$ & $32.8(1.0)$ & $27.5(2.1)$ & $30.9(1.0)$ & -3.5 & 0.26 & $0.0(2.0)$ & 1.00 & $-3.4(3.1)$ & 0.27 \\
\hline $36.7(1.0)$ & $36.0(1.0)$ & $34.7(1.3)$ & $36.2(1.0)$ & $-2.0(2.3)$ & 0.38 & $-0.5(2.0)$ & 0.82 & $-1.5(2.3)$ & 0.50 \\
\hline $40.5(1.0)$ & $36.8(1.0)$ & $33.8(1.6)$ & $37.6(1.0)$ & $-6.7(2.6)$ & 0.01 & $-2.8(2.0)$ & 0.16 & $-3.8(2.6)$ & 0.14 \\
\hline $35.0(1.0)$ & $33.7(1.0)$ & $33.1(1.1)$ & $33.8(1.0)$ & $-1.9(2.1)$ & 0.37 & $-1.2(2.0)$ & 0.54 & $-0.7(2.1)$ & 0.75 \\
\hline $29.7(1.0)$ & $29.8(1.0)$ & $28.8(1.2)$ & $30.0(1.0)$ & $-0.9(2.2)$ & 0.68 & $0.3(2.0)$ & 0.90 & $-1.2(2.2)$ & 0.60 \\
\hline
\end{tabular}




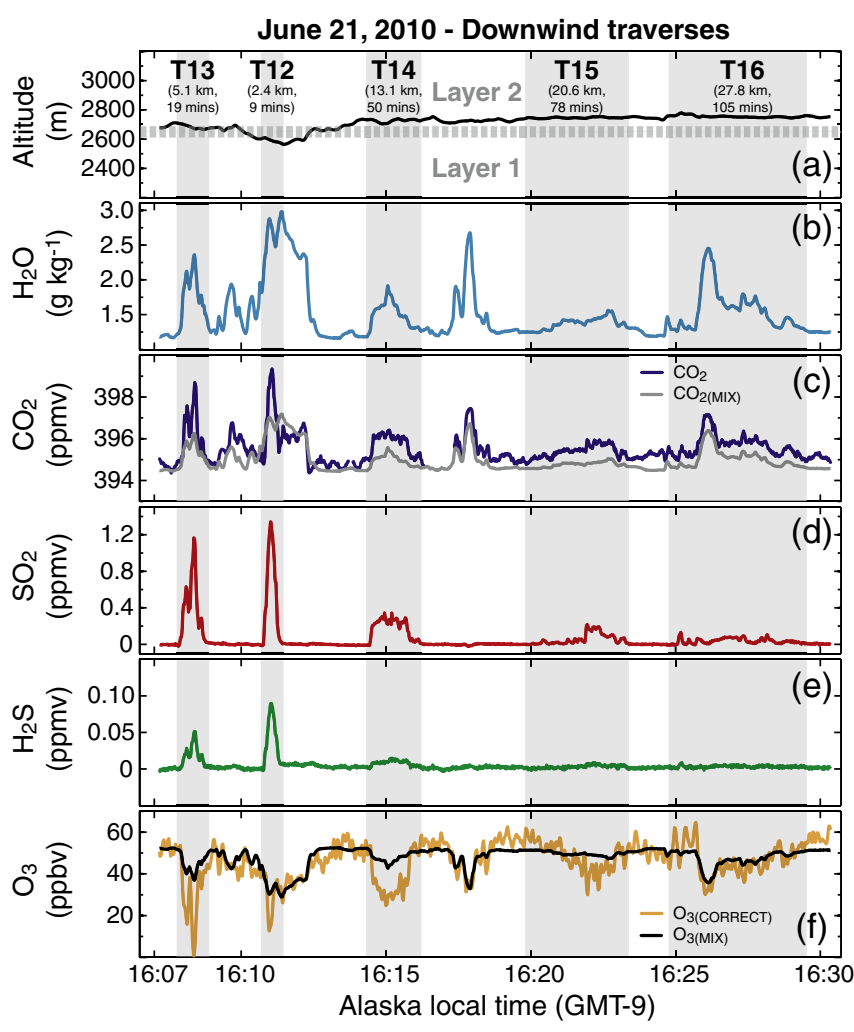

Fig. 5. June 21, 2010 in situ time series data showing mixing ratios and GPS altitudes from downwind traverses. The traverses are numbered in order of increasing distance from the volcano and are shown with the corresponding distance downwind and calculated plume travel time. Plume transects are shaded light gray. The transition from ambient air Layer 1 to Layer 2 at 2600-2700 $\mathrm{m}$ altitude is shown in (a) and marked with a dashed line. Model $\mathrm{O}_{3(\text { mix })}$ and $\mathrm{CO}_{2(\text { mix })}$ mixing ratios are shown in (c) and (f). See sections 5.1 and 5.2 for details.

concentrations progressively decreased with distance from the lava dome and clearly show the horizontal broadening of the plume with distance downwind. Intense $\mathrm{O}_{3}$ depletions in traverses 12 and 13 broaden into a wide depletion in traverse 14 and become less obvious and more poorly correlated with $\mathrm{SO}_{2}$ in traverses 15 and 16 . In the ideal case, the in situ downwind measurements would sample emissions with the same crosswind integrated concentration (area under the in situ plume peaks) at each traverse. The crosswind integrated $\mathrm{SO}_{2}$ concentrations (Table 3) for traverses 12-14 are comparable but for traverses 15 and 16 are lower by a factor of $\sim 2$ to 3 , indicating that either (1) the plume was displaced to another altitude, (2) emissions varied by a factor of 2 to 3 during the sampling period, or (3) that $\mathrm{SO}_{2}$ was not conserved. We favor option 1 but cannot distinguish between these possibilities with the data at hand. Sampling at multiple altitudes downwind would help resolve this question in future studies.

\subsection{August 19, 2010 airborne results}

\subsubsection{Airborne in situ sampling}

The goal of the August 19 flight was to obtain observations of the plume's chemical evolution with time using a combination of in situ and remote FLYSPEC measurements (discussed in the next section). We did not make ladder traverses but rather focused on making in situ and remote downwind traverses. We made a total of 14 downwind traverses, of which 6 were made for in situ measurements and 8 were made for remote UV observations. Weather conditions on August 19 were similar to those on June 21: mostly clear with scattered cumulus clouds at $\sim 2600 \mathrm{~m}$ and much higher and intermittent cirrostratus clouds. Unfortunately the cumulus clouds did interfere somewhat with the measurements, as we explain below. The average wind speed was $4.7 \mathrm{~m} \mathrm{~s}^{-1}(\mathrm{n}=5)$ with a range of $4.0-5.8 \mathrm{~m} \mathrm{~s}^{-1}$. The wind direction was consistent and from the northwest $\left(320^{\circ}\right)$ during the flight.

Vertical profiles (Fig. 3g-1) show a similar temperature structure to June 21 . A small inversion at $\sim 2600 \mathrm{~m}$ separated relatively moist air from drier air above. Overall conditions were slightly cooler, lower in $\mathrm{CO}_{2}$, and lower in $\mathrm{O}_{3}$ than on June 21. The atmosphere was less stratified and ambient mixing ratios showed progressive variations from 2500 to $3000 \mathrm{~m}$ rather than an abrupt change. Above $\sim 2600 \mathrm{~m}$ altitude, $\mathrm{H}_{2} \mathrm{O}$ mixing ratios generally decreased, while ambient $\mathrm{CO}_{2}$ and $\mathrm{O}_{3}$ mixing ratios generally increased, with altitude.

The 6 in situ traverses were made between 12:13 to 12:18 (traverses 1 and 2) and 13:27 to 13:50 AKDT (traverses 12-15). The results are shown in Fig. 6 and summarized in Table 3. Observations beneath the plume using the remote instruments were made in the time period between the in situ observations. The in situ measurements were made from 5.1 to $18.3 \mathrm{~km}$ downwind from the lava dome ( 18 to 65 min plume travel time). $\mathrm{SO}_{2}$ comprised about $97 \%$ (molar) of $\mathrm{S}_{\text {total }}$. The highest concentrations were encountered during traverse 2 at $2600 \mathrm{~m}$ altitude. The maximum observed mixing ratios were $2.15 \pm 0.22$ ppmv and $0.06 \pm 0.02$ ppmv for $\mathrm{SO}_{2}$ and $\mathrm{H}_{2} \mathrm{~S}$, respectively. $\mathrm{CO}_{2}$ was up to $9.4 \pm 0.3$ ppmv above background. The only large $\mathrm{O}_{3}$ depletion was observed during traverse 2 , with a minimum $\mathrm{O}_{3}$ of $9 \pm 9$ ppbv (approximately $70 \%$ below ambient levels) although a broader deficit was present during traverse 1 and a small deficit was apparent during traverse 12 . Unfortunately cumulus clouds present at $2500-2800 \mathrm{~m}$ altitude downwind prevented us from making the downwind traverses at a constant altitude. For this reason the downwind traverses do not follow the expected

\section{August 2010 - Downwind traverses}

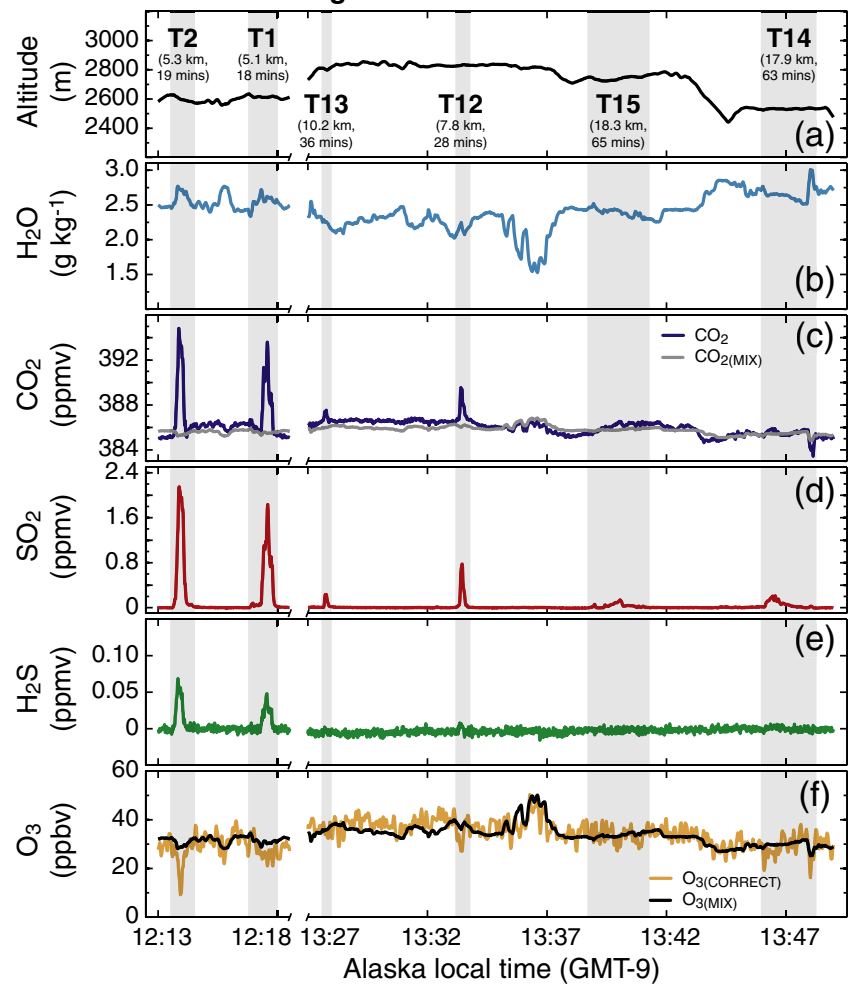

Fig. 6. August 19, 2010 in situ time series data showing mixing ratios and GPS altitudes from downwind traverses. The traverses are numbered in order of increasing distance from the volcano and are shown with the corresponding distance downwind and calculated plume travel time. Plume transects are shaded light gray. Note the break in time on the $\mathrm{x}$-axis. Model $\mathrm{O}_{3 \text { (mix) }}$ and $\mathrm{CO}_{2 \text { (mix) }}$ mixing ratios are shown in (c) and (f). See sections 5.1 and 5.2 for details. 
progressive widening of the plume with time since different parts of the plume were sampled during each traverse. Traverses 12 and 13 were likely sampled near the top edge of the plume whereas traverse 14 likely sampled near the plume bottom. This is clearly shown by the crosswind integrated $\mathrm{SO}_{2}$ concentrations, which vary from 150 to 3270 ppmv m (Table 3).

\subsubsection{Airborne spectroscopic retrievals of $\mathrm{SO}_{2}$ and $\mathrm{BrO}$}

The spectra available for $\mathrm{BrO}$ evaluation were recorded on August 19 between 12:20 to 13:25 and 13:50 to 14:05 AKDT at distances of between 5.9 and $18.2 \mathrm{~km}$ from the lava dome (21 to $65 \mathrm{~min}$ plume travel time). Due to the prevailing conditions, remote spectroscopic measurements were made beneath the 100-200 m thick cumulus cloud layer and there is evidence to suggest multiple scattering (e.g. Kern et al., 2010 ) in this layer (and possibly other radiative effects) significantly impacted the measurements. On August $19, \mathrm{SO}_{2}$ observations from both FLYSPEC and COSPEC yielded maximum column densities of around $500-600 \mathrm{ppm} \mathrm{m}$, a significantly higher value than the 80-100 ppm m obtained in similar locations under cloud-free conditions the very next day (August 20th; Werner et al., 2013). There is no independent indication of a 6 -fold increase in $\mathrm{SO}_{2}$ degassing on August 19 when compared to values obtained on August 20 or those found in June, and the high column densities are almost certainly attributed to multiple scattering in the volcanic plume and the partially superimposed cumulous cloud. While the enhancement of optical path length in the plume inhibits an accurate determination of vertical $\mathrm{SO}_{2}$ column or emission rate, the retrieval of the molecular ratio of $\mathrm{BrO} /$ $\mathrm{SO}_{2}$ is not significantly impacted. In fact, the enhanced light path increased the instrumental sensitivity to absorbing species in the plume, thereby making the detection of $\mathrm{BrO}$ possible.

Keeping in mind that the retrieved column densities do not correspond to vertical columns, the BrO column density we derived for each spectrum is shown as a function of the obtained $\mathrm{SO}_{2}$ column density in Fig. 7. While limited in its extent, the dataset does indeed contain several spectra in which BrO could be positively and unambiguously identified.

Significant positive detection of BrO could only be achieved for spectra recorded during traverses at $6 \mathrm{~km}$ from the lava dome (blue diamonds in Fig. 7), where an $\mathrm{SO}_{2}$ column density of up to

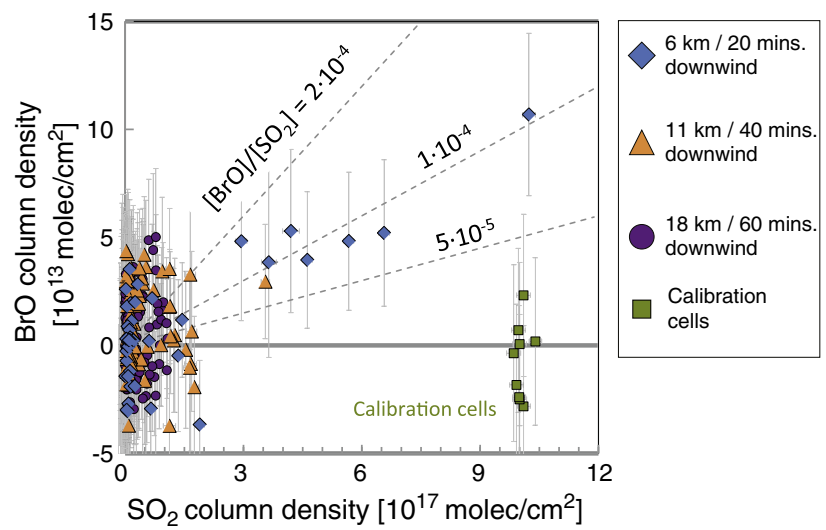

Fig. 7. August 19, 2010 airborne UV-DOAS data showing retrieved BrO column density as a function of $\mathrm{SO}_{2}$ column density. Blue diamonds indicate spectra collected at $6 \mathrm{~km}$ $(\sim 20 \mathrm{~min})$, orange triangles represent measurements at about $11 \mathrm{~km}(\sim 40 \mathrm{~min})$, and purple circles show results obtained at approximately $18 \mathrm{~km}(\sim 1 \mathrm{~h})$ from the lava dome. Green crosses show the results of spectra collected away from the volcanic plume but with a calibration cell containing $\mathrm{SO}_{2}$ in the light path. These points illustrate the instrument accuracy and precision and were included to demonstrate that the dataset, while limited in its extent, does indeed contain several spectra in which $\mathrm{BrO}$ could be positively and unambiguously identified. The dashed lines show that the data collected $6 \mathrm{~km}$ downwind are consistent with $\mathrm{BrO} / \mathrm{SO}_{2}=1 \cdot 10^{-4}$.
$1 \cdot 10^{18}$ molecules $/ \mathrm{cm}^{2}$ (about $520 \mathrm{ppm} \mathrm{m}$; path length concentrations calculated at plume $\mathrm{P}=730 \mathrm{hPa}$ and $\mathrm{T}=0{ }^{\circ} \mathrm{C}$ ) was obtained. The molecular $\mathrm{BrO} / \mathrm{SO}_{2}$ ratio at this distance is compatible with $1 \cdot 10^{-4}$, but the limited nature of the acquired dataset leads to a large uncertainty in this value. Further downwind, the plume was too dilute to allow an unambiguous detection of BrO. For the traverses conducted at around $11 \mathrm{~km}$ distance, the maximum $\mathrm{SO}_{2}$ column density obtained in a 15 second interval was $3.6 \cdot 10^{17}$ molecules $/ \mathrm{cm}^{2}$ $(\sim 190 \mathrm{ppm} \mathrm{m})$. Retrieved BrO column densities were below $4 \cdot 10^{13}$ molecules $/ \mathrm{cm}^{2}$, and were fairly evenly scattered around null, so a positive detection could not be achieved. The data recorded at $18 \mathrm{~km}$ distance indicates a further dilution of the plume by an additional factor of 3, and $\mathrm{BrO}$ was again below the detection limit

The average mixing ratio of $\mathrm{BrO}$ in the plume can only be roughly estimated if an assumption about the effective optical path length in the plume is made. Assuming an emission rate and plume geometry similar to that observed the next day under cloud free conditions, the effective light path appears to have been enhanced by a factor of 6 compared to the vertical plume extent $(\sim 1800-3000 \mathrm{~m}$ as opposed to 300 to $500 \mathrm{~m}$ ) during the August 19 measurements. These values imply a positive detection of approximately 20-30 pptv of $\mathrm{BrO}$ in the plume at $6 \mathrm{~km}$ from the vent and an upper limit for the BrO mixing ratio of about $10-20$ pptv at $11 \mathrm{~km}$ distance. While these numbers should only be regarded as very rough estimates, they give some indication as to the average $\mathrm{BrO}$ concentration present in the plume, and show that this concentration appears to have decreased between 6 and $11 \mathrm{~km}$ (between $\sim 20$ and 40 min after emission).

\section{Discussion}

\subsection{The causes of in-plume $\mathrm{O}_{3}$ anomalies}

Interpreting the in-plume $\mathrm{O}_{3}$ data is not straightforward because both dynamic (i.e. entrainment, mixing, transport) and chemical processes may have played significant roles in determining the observed plume $\mathrm{O}_{3}$ compositions. Taking note of ambient $\mathrm{O}_{3}$ levels is especially important because on both June 21 and August 19 buoyant volcanic gases initially entrained relatively low- $\mathrm{O}_{3}$ ambient air before vertical transport lofted the plume into air with a different, higher, $\mathrm{O}_{3}$ composition (Fig. 3). An example of an anomaly due to the contrasting ambient compositions is seen on June 21 between traverses 10 and 11 (Fig. 4), where Layer 1 air with higher $\mathrm{H}_{2} \mathrm{O}\left(+1.5 \mathrm{~g} \mathrm{~kg}^{-1}\right)$, higher $\mathrm{CO}_{2}$ (+2.5 ppmv), and much lower $\mathrm{O}_{3}(-20 \mathrm{ppbv})$ mixing ratios stands out from the Layer 2 background. In this way, the plume may have inherited a compositional anomaly from the stratified atmosphere that gives the impression of low $\mathrm{O}_{3}$, elevated $\mathrm{H}_{2} \mathrm{O}$, and elevated $\mathrm{CO}_{2}$ mixing ratios in the plume. Since these are all features we might expect to find in a chemically active volcanic plume, we must carefully evaluate the data to identify what caused the anomalies we observed.

In the following discussion we define the total in-plume $\mathrm{O}_{3}$ anomaly $\left(\Delta \mathrm{O}_{3 \text { (total) }}\right)$ as the difference between the in-plume $\mathrm{O}_{3}$ mixing ratio (corrected for $\mathrm{SO}_{2}$ interference; $\mathrm{O}_{3}$ (correct) ) and the background $\mathrm{O}_{3}$ mixing ratio in ambient air $\left(\mathrm{O}_{3}(\mathrm{bg})\right)$ :

$\Delta \mathrm{O}_{3(\text { total })}=\mathrm{O}_{3(\text { correct })}-\mathrm{O}_{3(\mathrm{bg})}$.

$\mathrm{O}_{3(\mathrm{bg})}$ is determined by linearly interpolating between mixing ratios observed in ambient air just outside of the plume (Fig. 8) during each traverse, with the plume edges defined by the detection limit of the $\mathrm{SO}_{2}$ instrument $(0.020 \mathrm{ppmv})$. We calculated mean values and standard errors for each plume traverse due to the large random uncertainty of individual $\mathrm{O}_{3}$ measurements (as described in Section 3.4 and Appendix A). These mean values and their uncertainties are summarized in Table 3. The uncertainty of $\Delta \mathrm{O}_{3 \text { (total) }}$ was calculated by 


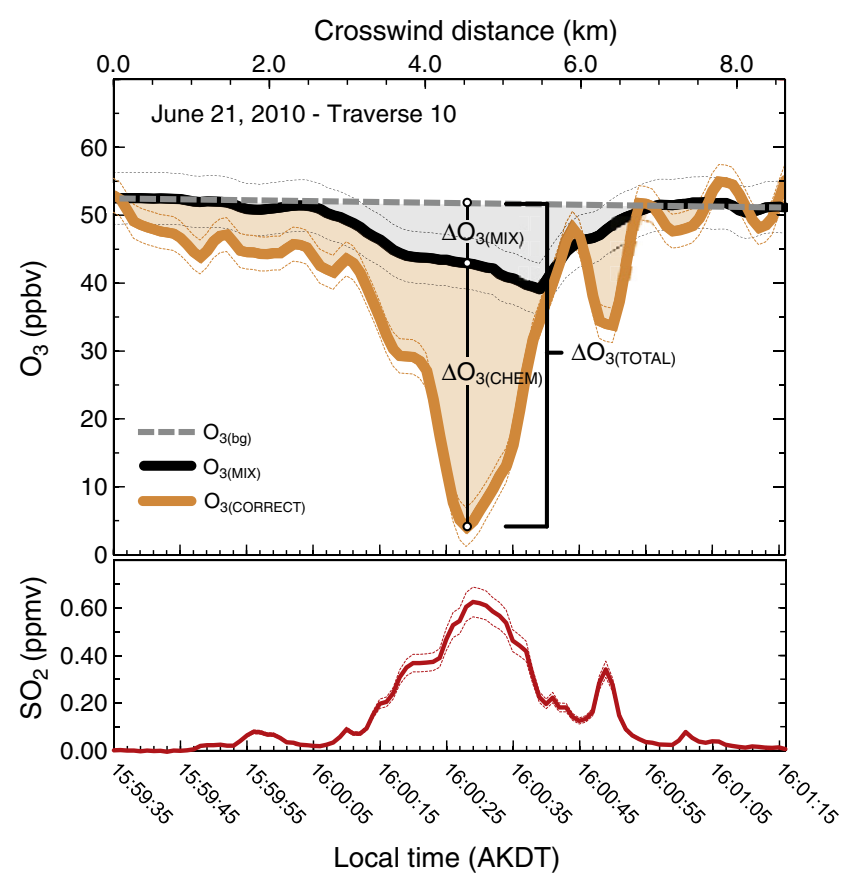

Fig. 8. An example of a plume transect (June 21, 2010, traverse 10) showing the measured $\mathrm{O}_{3}$ corrected for $\mathrm{SO}_{2}$ interference $\left(\mathrm{O}_{3}\right.$ (correct) $)$ and $\mathrm{SO}_{2}$ mixing ratios, as well as the derived $\mathrm{O}_{3}$ due to entrainment and mixing of ambient air $\left(\mathrm{O}_{3(\text { mix })}\right)$ and the inferred $\mathrm{O}_{3}$ background $\left(\mathrm{O}_{3(\mathrm{bg})}\right) .1 \sigma$ uncertainty for $\mathrm{O}_{3 \text { (correct) }}, \mathrm{O}_{3 \text { (mix) }}$, and $10 \%$ relative uncertainty shown with light dashed lines. Also indicated are the total in-plume $\mathrm{O}_{3}$ anomaly versus background $\left(\Delta \mathrm{O}_{3 \text { (total) }}\right)$, the anomaly due to entrainment and mixing of ambient air $\left(\Delta \mathrm{O}_{3(\mathrm{mix})}\right)$, and the anomaly due to in-plume chemical reactions $\left(\Delta \mathrm{O}_{3(\mathrm{chem})}\right)$.

linearly propagating the uncertainties associated with $\mathrm{O}_{3 \text { (correct) }}$ and $\mathrm{O}_{3(\mathrm{bg})}$.

The average $\Delta \mathrm{O}_{3 \text { (total) }}$ values show that in-plume $\mathrm{O}_{3}$ anomalies could be identified with greater than $95 \%$ confidence $(p<0.05)$ in 13 of 16 traverses on June 21. In contrast, on August 19 only 1 out of 6 traverses has an $\Delta \mathrm{O}_{3 \text { (total) }}$ with greater than $95 \%$ confidence (T12, $\Delta \mathrm{O}_{3 \text { (total) }}=-6.7 \pm 2.6 \mathrm{ppbv}, \mathrm{p}=0.01$ ), although the $\Delta \mathrm{O}_{3 \text { (total) }}$ value for T2 $(-5.8 \pm 3.6 \mathrm{ppbv})$ is significant at about $90 \%$ confidence $(p=0.11)$. Yet, what caused the low in-plume $\mathrm{O}_{3}$ ? Were these anomalies inherited from the atmosphere, created by chemical reactions, or both? In the next sections we describe an approach to distinguish between the dynamic and chemical processes responsible for the "missing" in-plume $\mathrm{O}_{3}$. We primarily discuss data from the larger June 21 dataset, but the same methodology is applied to the August 19 data.

\subsubsection{Identifying entrainment of ambient air}

One approach to decipher the impact entrainment of heterogeneous ambient air had on the plume composition is to identify a chemical tracer that recorded the entrainment and mixing process. We chose $\mathrm{H}_{2} \mathrm{O}$ for two reasons: first, $\mathrm{H}_{2} \mathrm{O}$ was strongly correlated with $\mathrm{O}_{3}$ and $\mathrm{CO}_{2}$ in ambient air (Fig. 9) which makes it a useful proxy for these species. Second, several lines of evidence argue that the component of volcanic $\mathrm{H}_{2} \mathrm{O}$ in the plume was small compared to $\mathrm{H}_{2} \mathrm{O}$ from the atmosphere. Here we define volcanic $\mathrm{H}_{2} \mathrm{O}$ as primary magmatic $\mathrm{H}_{2} \mathrm{O}$ (i.e. $\mathrm{H}_{2} \mathrm{O}$ that was degassed directly from magma) plus $\mathrm{H}_{2} \mathrm{O}$ volatilized from other hydrothermal, meteoric, or surface sources. In the simplest sense, given that $\mathrm{SO}_{2}$ was present at concentrations of only $\sim 1$ ppmv or less (i.e. diluted by factors of $\sim 10^{-4}$ to $10^{-5}$ assuming an Arc Mean initial $\mathrm{SO}_{2}$ mole fraction of 0.0144 ; Gerlach, 2004), it should follow that volcanic $\mathrm{H}_{2} \mathrm{O}$ was also very dilute. We can make a rough estimate of the amount of magmatic $\mathrm{H}_{2} \mathrm{O}$ expected to be in the plume if we assume that the initial volcanic gas had an Arc Mean molar $\mathrm{H}_{2} \mathrm{O} / \mathrm{SO}_{2}$ ratio ( 64; Gerlach, 2004) and that both species were conserved. In this case, the most concentrated volcanic gases we measured ( $1.34 \pm 0.13 \mathrm{ppmv} \mathrm{SO}_{2}$, traverse 12 ) would have had a maximum of $\sim 0.1 \mathrm{mmol} \mathrm{mol}^{-1}$ magmatic $\mathrm{H}_{2} \mathrm{O}$ (equivalent to $0.06 \mathrm{~g} \mathrm{~kg}^{-1}$ ), or only $\sim 2 \%$ of the observed peak $\mathrm{H}_{2} \mathrm{O}$ during traverse 12 (3.0 $\mathrm{g} \mathrm{kg}^{-1}$; Fig. 6). However, since volcanic $\mathrm{H}_{2} \mathrm{O}$ emissions are typically mixtures of primary magmatic $\mathrm{H}_{2} \mathrm{O}$ plus $\mathrm{H}_{2} \mathrm{O}$ from other sources (e.g. Symonds et al., 1990) this estimate likely significantly underestimates the total amount of volcanic $\mathrm{H}_{2} \mathrm{O}$ in the plume, possibly by an order of magnitude. Even so, the observations are not consistent with a large volcanic $\mathrm{H}_{2} \mathrm{O}$ component in the plume. $\mathrm{SO}_{2}$ and $\mathrm{H}_{2} \mathrm{O}$ variations within the plume were poorly correlated in most cases and on June 21 higher $\mathrm{H}_{2} \mathrm{O}$ mixing ratios were found in ambient air in Layer 1 than in the plume itself. Indeed, significant positive in-plume $\mathrm{H}_{2} \mathrm{O}$ anomalies were only found above $2600 \mathrm{~m}$ altitude where the background air was drier (e.g. traverses 4, 10, 11; Fig. 4). While we cannot exclude that volcanic $\mathrm{H}_{2} \mathrm{O}$ made up some component of the variations we observed, the data at hand strongly suggest that atmospheric $\mathrm{H}_{2} \mathrm{O}$ was much more abundant in the plume.

Accepting that the $\mathrm{H}_{2} \mathrm{O}$ we observed in the plume was primarily atmospheric in origin, we may calculate the expected $\mathrm{O}_{3}$ mixing ratios in the plume based on the observed ambient $\mathrm{O}_{3}: \mathrm{H}_{2} \mathrm{O}$ relationship shown in Fig. 9:

$\mathrm{O}_{3(\operatorname{mix})}=-12.9\left[\mathrm{H}_{2} \mathrm{O}\right]+67.5$

where $\left[\mathrm{H}_{2} \mathrm{O}\right]$ is the mixing ratio $\left(\mathrm{g} \mathrm{kg}^{-1}\right)$ and $\mathrm{O}_{3(\mathrm{mix})}$ is the calculated plume $\mathrm{O}_{3}$ composition (ppbv) expected only from entrainment and mixing of ambient air into the plume (i.e. no plume chemistry). The results are shown in the time series plots (Figs. 4, 5, and 6) and are summarized in Table 3. Based on the regression residuals (Fig. 9), we estimate the random uncertainty on individual model values to

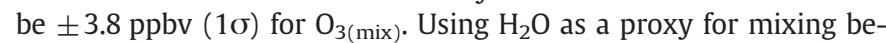
tween the ambient air layers can account for both negative $\mathrm{O}_{3}$ anomalies (e.g. between traverses 10 and 11) and positive $\mathrm{O}_{3}$ anomalies (e.g. between traverses 7 and 8) we observed (Fig. 4). The measurements reveal the highly variable small-scale advection and mixing

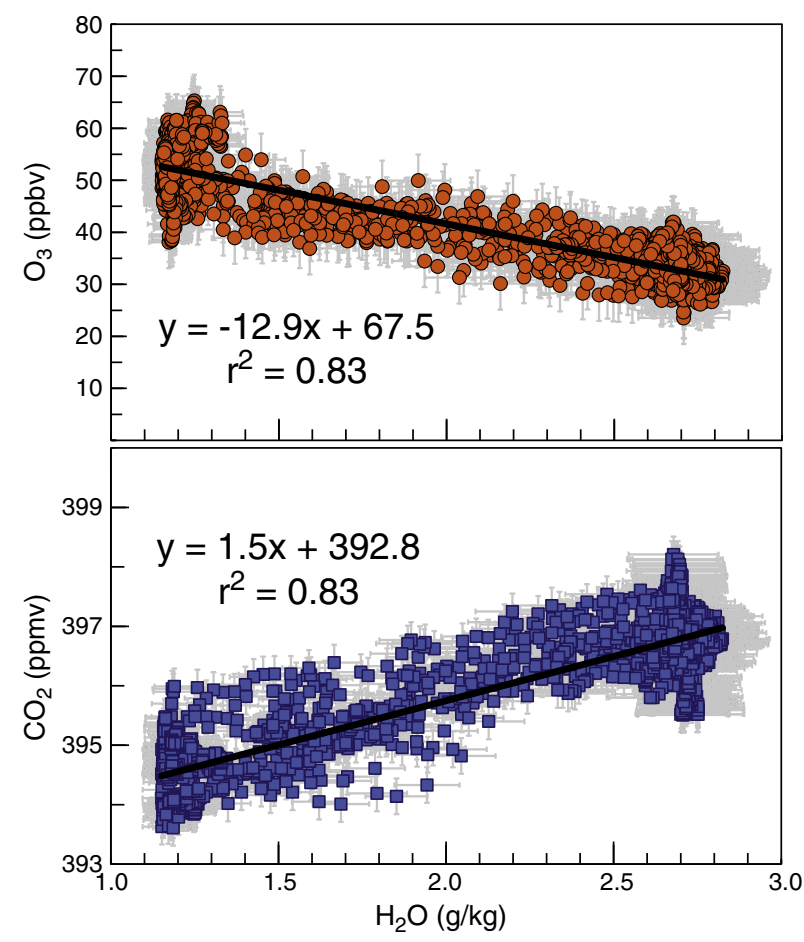

Fig. 9. The observed relationships between $\mathrm{H}_{2} \mathrm{O}$ and $\mathrm{O}_{3}$, and $\mathrm{H}_{2} \mathrm{O}$ and $\mathrm{CO}_{2}$ in ambient air between 2500 and $3000 \mathrm{~m}$ altitude $(\mathrm{n}=4126)$ on June $21,2010 . \mathrm{O}_{3}$ and $\mathrm{CO}_{2}$ are shown with $2 \sigma$ uncertainty and $\mathrm{H}_{2} \mathrm{O}$ with $5 \%$ relative uncertainty. 
processes that were occurring between the stratified atmosphere and the volcanic plume.

Using the calculated $\mathrm{O}_{3(\mathrm{mix})}$ values we can calculate the anomaly due to mixing and entrainment of ambient air into the plume, $\Delta \mathrm{O}_{3 \text { (mix) }}$ by difference according to:

$\Delta \mathrm{O}_{3(\mathrm{mix})}=\mathrm{O}_{3(\mathrm{mix})}-\mathrm{O}_{3(\mathrm{bg})}$

Inspection of the $\Delta \mathrm{O}_{3(\mathrm{mix})}$ results (Table 3 ) reveals that entrainment of low- $\mathrm{O}_{3}$ air (i.e. Layer 1, Fig. 3) had a significant $(\mathrm{p}<0.05)$ impact on 9 out of 16 traverses on June 21. In some cases, such as traverse 5 , a large negative $\mathrm{O}_{3}$ anomaly $\left(\Delta \mathrm{O}_{3 \text { (total })}=-10.9 \pm 2.4\right.$ ppbv, $\mathrm{p}=<0.01$ ) can be wholly attributed to entrainment of low- $\mathrm{O}_{3}$ air into the plume (T5 $\Delta \mathrm{O}_{3(\mathrm{mix})}=-10.0 \pm 2.0, \mathrm{p}=<0.01$ ). Another important finding is that the large negative $\mathrm{O}_{3}$ anomaly observed during the most distal traverse (T16: $27.8 \mathrm{~km} / 105 \mathrm{~min}$ downwind, $\Delta \mathrm{O}_{3 \text { (total) }}=-8.6 \pm 2.1 \mathrm{ppbv}$ ) can be explained by entrainment of ambient air $\left(\Delta \mathrm{O}_{3 \text { (mix })}=-7.6 \pm 2.0\right)$ and thus did not require significant chemical $\mathrm{O}_{3}$ loss.

Failing to recognize the contribution of atmospheric heterogeneity to $\Delta \mathrm{O}_{3 \text { (total) }}$ would complicate interpretation of the data and result in potentially very large overestimates of $\mathrm{O}_{3}$ depletion due to in-plume chemical processes. For example, about half of the largest $\mathrm{O}_{3}$ depletion we observed (T13, $\Delta \mathrm{O}_{3 \text { (total) }}=-23.2 \pm 3.6 \mathrm{ppbv}$ ) can be attributed to entrainment of low- $\mathrm{O}_{3}$ air into the plume (T13, $\Delta \mathrm{O}_{3 \text { (mix) }}=$ $-11.1 \pm 2.0$ ). On the other hand, ambient heterogeneity did not have significant impact (at $\mathrm{p}<0.05$ ) on any traverses on August 19 and can largely be neglected.

\subsubsection{Identifying chemical $\mathrm{O}_{3}$ loss}

After accounting for entrainment of heterogeneous ambient air into the plume, we may evaluate the change in plume $\mathrm{O}_{3}$ due to chemical reactions. We define the plume $\mathrm{O}_{3}$ anomaly that can be attributed to in-plume chemistry $\left(\Delta \mathrm{O}_{3(\mathrm{chem})}\right)$ as the difference between the inplume $\mathrm{O}_{3}$ mixing ratio (corrected for $\mathrm{SO}_{2}$ interference; $\mathrm{O}_{3 \text { (correct) }}$ ) and the calculated plume $\mathrm{O}_{3}$ composition expected from entrainment and mixing of ambient air into the plume $\left(\mathrm{O}_{3(\mathrm{mix})}\right)$ :

$$
\Delta \mathrm{O}_{3(\text { chem })}=\mathrm{O}_{3 \text { (correct) }}-\mathrm{O}_{3 \text { (mix) }} \text {. }
$$

Table 3 shows that chemical $\mathrm{O}_{3}$ loss was identified with greater than $95 \%$ confidence in 9 out of 16 traverses on June 21 . The ladder traverses (traverses 1-5) show chemical $\mathrm{O}_{3}$ loss was greater near the vertical center of the plume (traverses $3,4,10$, and 11) than near the top and bottom edges (traverses 1,2, and 5). The COSPEC traverses (T6-9) yielded highly variable results. Each traverse encountered different levels of in situ $\mathrm{SO}_{2}$ and the calculated mean $\Delta \mathrm{O}_{3 \text { (chem) }}$ ranged from insignificant (T6, $\Delta \mathrm{O}_{3(\mathrm{chem})}=-1.0 \pm 2.1 \mathrm{ppbv}, \mathrm{p}=0.62$ ) to the largest detected $\left(\mathrm{T} 9, \Delta \mathrm{O}_{3(\mathrm{chem})}=-16.3 \pm 2.7 \mathrm{ppbv}, \mathrm{p}=<0.01\right)$. The closest traverse (T12, $2.4 \mathrm{~km} / 9 \mathrm{~min}$ ) showed some chemical $\mathrm{O}_{3}$ loss but the high levels of $\mathrm{SO}_{2}$ encountered resulted in considerable uncertainty $\left(\Delta \mathrm{O}_{3(\mathrm{chem})}=-4.1 \pm 3.8, \mathrm{p}=0.29\right)$. The downwind traverses show that the largest $\Delta \mathrm{O}_{3 \text { (chem) }}$ deficits occurred after about 20-50 min ( 7-13 km) of processing. Gridded models showing the downwind horizontal dispersion of $\mathrm{SO}_{2}$ and $\Delta \mathrm{O}_{3 \text { (chem) }}$ deficits in the plume are shown in Fig. 10.

In contrast, chemical $\mathrm{O}_{3}$ loss could only be identified with up to $90 \%$ confidence in 1 out of 6 traverses on August $19\left(\mathrm{~T} 2, \Delta \mathrm{O}_{3 \text { (chem })}=\right.$ $-5.9 \pm 3.6, \mathrm{p}=0.10$ ) and with greater than $80 \%$ confidence in another $\left(\mathrm{T} 12, \Delta \mathrm{O}_{3(\mathrm{chem})}=-3.8 \pm 2.6, \mathrm{p}=0.14\right)$. The high $\mathrm{SO}_{2}$ levels encountered during traverses 1 and 2 resulted in large uncertainty in these measurements, and the poor conditions prevented us from sampling closer to the plume center during traverses $12-15$, as shown by their low crosswind integrated $\mathrm{SO}_{2}$ values (Table 3).
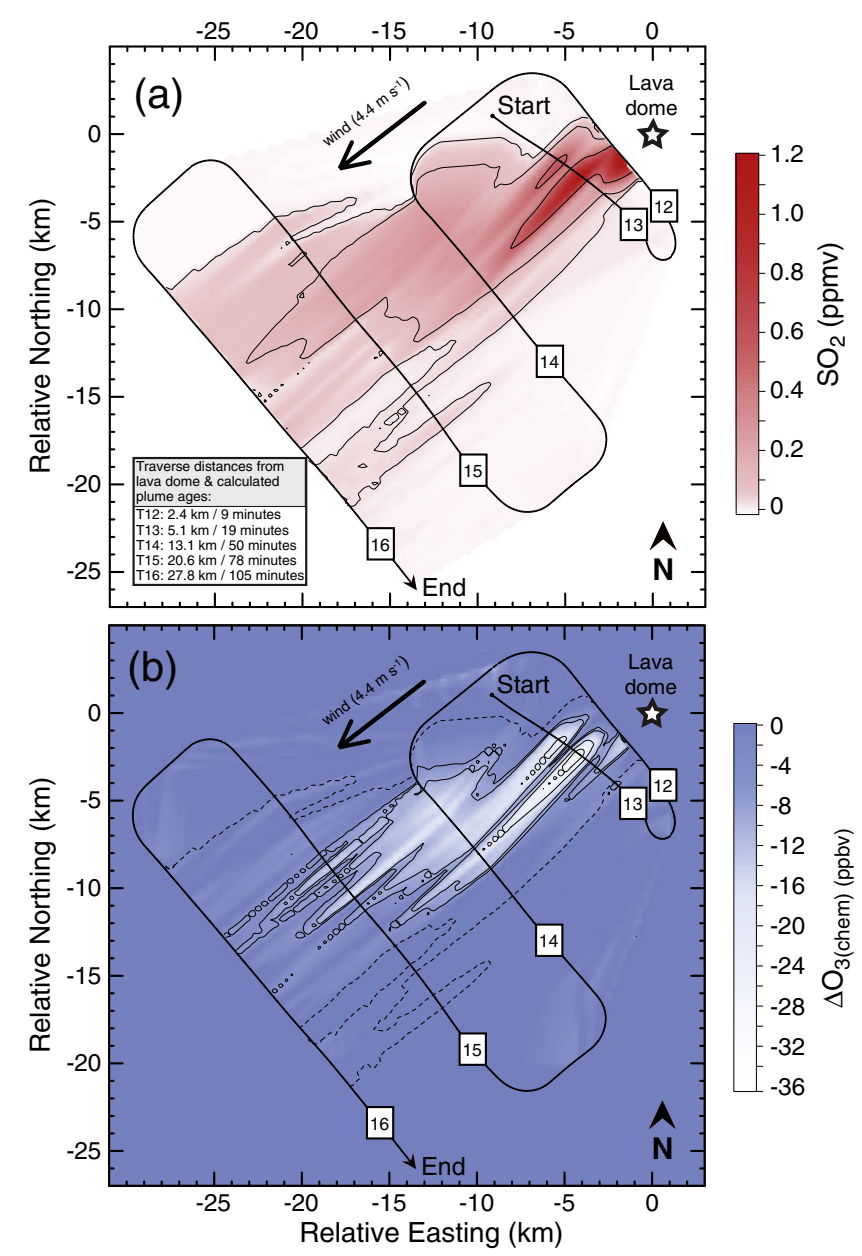

Fig. 10. June 21, 2010 GPS ground track of the downwind traverses (T12-T16) showing gridded $\mathrm{SO}_{2}$ and $\Delta \mathrm{O}_{3}$ (chem) values generated from the time series data shown in Fig. 5. The data were interpolated using a triangulation with linear interpolation function in the Surfer software package (Golden Software, $\mathrm{CO}$ ) and are intended to show general characteristics of plume dispersion and $\mathrm{O}_{3}$ destruction downwind. The plots show the horizontal dispersion of the plume at $\sim 2700 \mathrm{~m}$ altitude and the "ozone hole" that can be attributed to volcanic emissions $\left(\Delta \mathrm{O}_{3(\mathrm{chem})}\right)$. The contours on the top panel (a) correspond to $\mathrm{SO}_{2}$ mixing ratios of 0.02 (the instrumental detection limit), 0.10 , and $0.50 \mathrm{ppmv} \mathrm{SO}_{2}$. The dashed contours on the bottom panel (b) indicate the extent of the plume based on the $\mathrm{SO}_{2}$ measurements, and the solid contours represent $\mathrm{O}_{3}$ deficits of $-7,-10,-20$, and -30 ppbv. Note that the largest $\mathrm{O}_{3}$ depletions are found from $\sim 5$ to $13 \mathrm{~km}$ downwind (19 to 50 min plume travel time) and near the horizontal center of the plume.

\subsection{Identifying atmospheric vs. volcanic $\mathrm{CO}_{2}$}

As a corollary to the $\mathrm{O}_{3}$ discussion, we note that ambient heterogeneity can also complicate the interpretation of measurements of volcanic gases, such as $\mathrm{CO}_{2}$. The ratio of $\mathrm{CO}_{2}$ to other volcanic gases (e.g. $\mathrm{CO}_{2} / \mathrm{SO}_{2}$ ) is commonly used in volcano monitoring to infer information about subvolcanic processes and impending hazards (e.g. see Werner et al., 2013), so accurate determination of volcanic $\mathrm{CO}_{2}$ in plumes is critical.

On June 21 the plume initially entrained air with high $\mathrm{CO}_{2}$ and $\mathrm{H}_{2} \mathrm{O}$ but was then vertically transported into air with lower $\mathrm{CO}_{2}$ and $\mathrm{H}_{2} \mathrm{O}$ values (Fig. 3). Therefore the measured plume anomalies may reflect contributions from both atmospheric and volcanic $\mathrm{CO}_{2}$. The general method outlined in Section 5.1 can also be used to estimate the atmospheric $\mathrm{CO}_{2}$ contribution to the plume, based on the relationship of $\mathrm{H}_{2} \mathrm{O}$ and $\mathrm{CO}_{2}$ in ambient air (Fig. 9):

$\mathrm{CO}_{2 \text { (mix) }}=1.5\left[\mathrm{H}_{2} \mathrm{O}\right]+392.8$. 


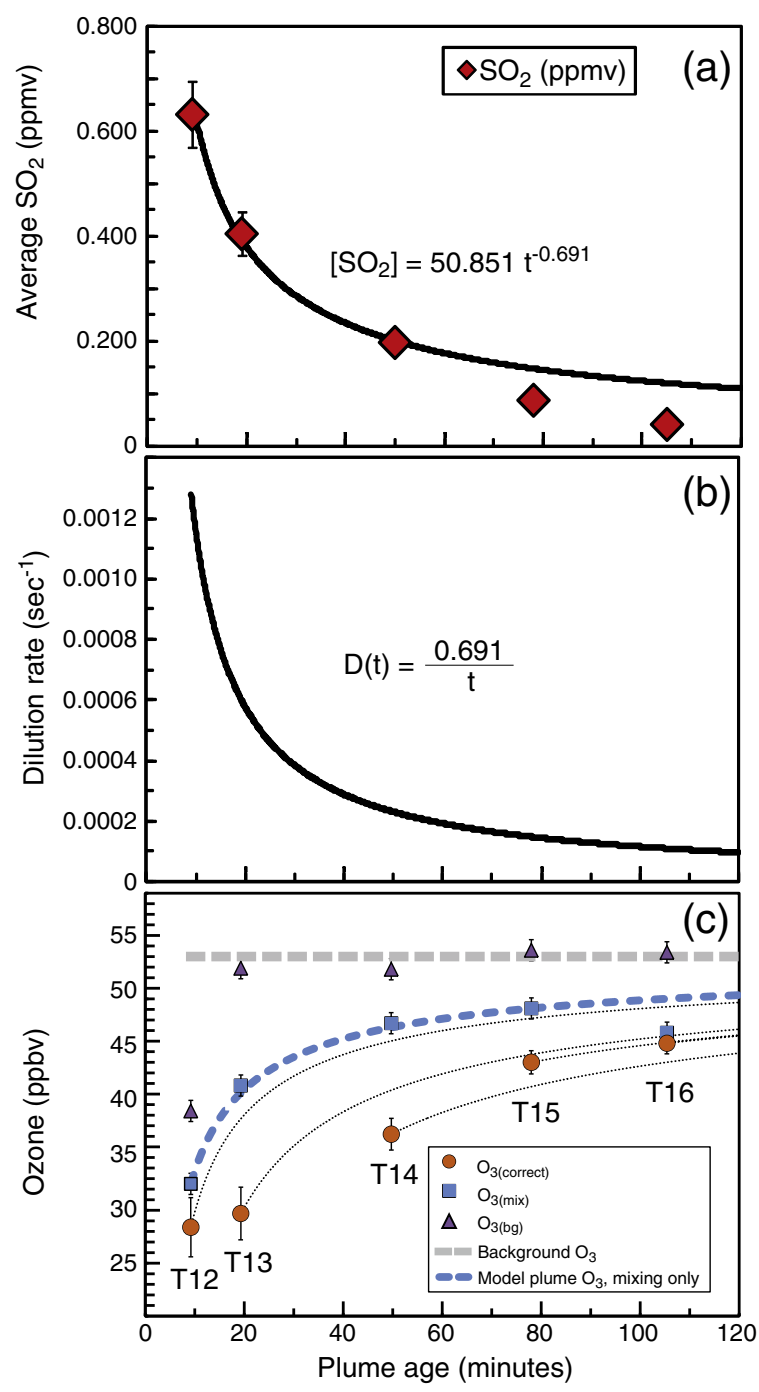

Fig. 11. Results from measurements (all data from Table 3) and models of downwind traverses (T12-T16) on June 21, 2010. Panel (a) shows the average $\mathrm{SO}_{2}$ for each of the 5 downwind traverses and a power function fit to data from T12-T13. Panel (b) shows the derived plume dilution rate with time. Panel (c) shows the projected evolution of the plume's mean $\mathrm{O}_{3}$ composition due to entrainment and mixing of ambient air along with observed values from Table 3 . The model mixing trajectories were calculated using Eqs. (7) and (9) (Section 5.3.1) to determine the change in the plume composition at 1 second intervals with the background ambient $\mathrm{O}_{3(\mathrm{bg})}$ set to $53 \mathrm{ppbv}$. The model $\mathrm{O}_{3(\mathrm{bg})}$ is indicated by the dashed gray line and constrained by the observed $\mathrm{O}_{3(\mathrm{bg})}$ mixing ratios (purple triangles). The blue squares are the calculated $\mathrm{O}_{3 \text { (mix) }}$ values, which represent the in-plume $\mathrm{O}_{3}$ composition due to entrainment and mixing of ambient air derived in Section 5.1.1. The thick blue dashed line represents evolution of the plume by mixing with background air, with the $\mathrm{O}_{3 \text { (mix) }}$ value from T12 as the starting plume $\mathrm{O}_{3}$ composition. The orange circles represent the observed $\mathrm{O}_{3}$ values corrected for $\mathrm{SO}_{2}$ interference $\left(\mathrm{O}_{3 \text { (correct) }}\right)$ for traverses $12-16$ and the light dashed lines show the calculated evolution of these values by mixing. The components that constitute the observed $\mathrm{O}_{3}$ deficits may be derived from the plot. For example, the total observed deficit $\left(\Delta \mathrm{O}_{3 \text { (total })}\right)$ is the distance between the purple triangle and the orange circle. The deficit due to entrainment and mixing of ambient air $\left(\Delta \mathrm{O}_{3 \text { (mix) }}\right)$ is the distance from the purple triangle to the blue square. The $\mathrm{O}_{3}$ deficit that can be attributed to in-plume chemical reactions $\left(\Delta \mathrm{O}_{3(\mathrm{chem})}\right)$ is the distance between the blue square and the orange circle. See section 5.3 .1 for more information.

$\mathrm{CO}_{2 \text { (mix) }}$ is the $\mathrm{CO}_{2}$ component (in ppmv) that can be attributed to entrainment and mixing of heterogeneous ambient air into the plume, and $\left[\mathrm{H}_{2} \mathrm{O}\right]$ is the $\mathrm{H}_{2} \mathrm{O}$ mixing ratio (in $\mathrm{g} \mathrm{kg}^{-1}$ ). The regression residuals indicate that random uncertainty on individual $\mathrm{CO}_{2 \text { (mix) }}$ values is relatively large $( \pm 0.4 \mathrm{ppmv}, 1 \sigma)$. The $\mathrm{CO}_{2(\mathrm{mix})}$ results are shown in Figs. 4-6. The calculated $\mathrm{CO}_{2 \text { (mix) }}$ values provide guidance for identifying volcanic $\mathrm{CO}_{2}$ anomalies in the June 21 data, which is difficult given the stratified atmosphere and low in-plume $\mathrm{CO}_{2}$ mixing ratios. This approach helps explain the negative in-plume $\mathrm{CO}_{2}$ anomalies we observed (e.g. traverses 6 and 7) and shows that volcanic $\mathrm{CO}_{2}$ can only be identified with confidence in traverses with the highest volcanic gas levels (e.g. traverses 4, 12, and 13). In contrast, on August 19 the plume was more concentrated and the atmosphere less stratified, which makes picking volcanic $\mathrm{CO}_{2}$ from the background more straightforward (Fig. 6). Thus, even though ambient heterogeneity may not always be significant, recognizing and determining its influence should be kept in mind when interpreting volcanic plume $\mathrm{CO}_{2}$ data.

\subsection{Chemical evolution of the plume}

\subsubsection{Chemical changes due to entrainment of ambient air}

In order to further investigate the interplay of chemical and dynamic processes with time, we can use the downwind data from June 21 to calculate a first-order estimate of the chemical evolution of the plume due to dilution over its first $\sim 2 \mathrm{~h}$ after release to the atmosphere. Two-component mixing between a plume and ambient air can be represented by a mixing law:

$\left.\frac{\mathrm{dC}_{\mathrm{pl}}}{\mathrm{dt}}\right|_{\text {mix }}=\left(\mathrm{C}_{\mathrm{bg}}-\mathrm{C}_{\mathrm{pl}}\right) \mathrm{D}(\mathrm{t})$

where $C_{b g}$ is the average homogeneous background concentration, $C_{p l}$ is the average plume concentration, and $\mathrm{D}(\mathrm{t})$ is the dilution rate, which is unknown. This simple expression assumes Gaussian dispersion of the plume and has been utilized by von Glasow et al. (2003) and Chosson et al. (2008) to model the dilution of ship exhaust plumes. In reality, plumes are highly spatially heterogeneous and dispersion is often influenced by turbulent mixing, atmospheric instabilities, or other factors not captured with this simple representation. For these reasons we stress that our results are limited in scope and are intended only as a general impression of how the composition of the plume changed with time due to entrainment of ambient air as it dispersed and aged.

To derive the dilution rate from our downwind data, first we fit a power law expression to the average $\mathrm{SO}_{2}$ values from traverses 12-14 (Table 3 ) and find the following to describe the average $\mathrm{SO}_{2}$ mixing ratio with time:

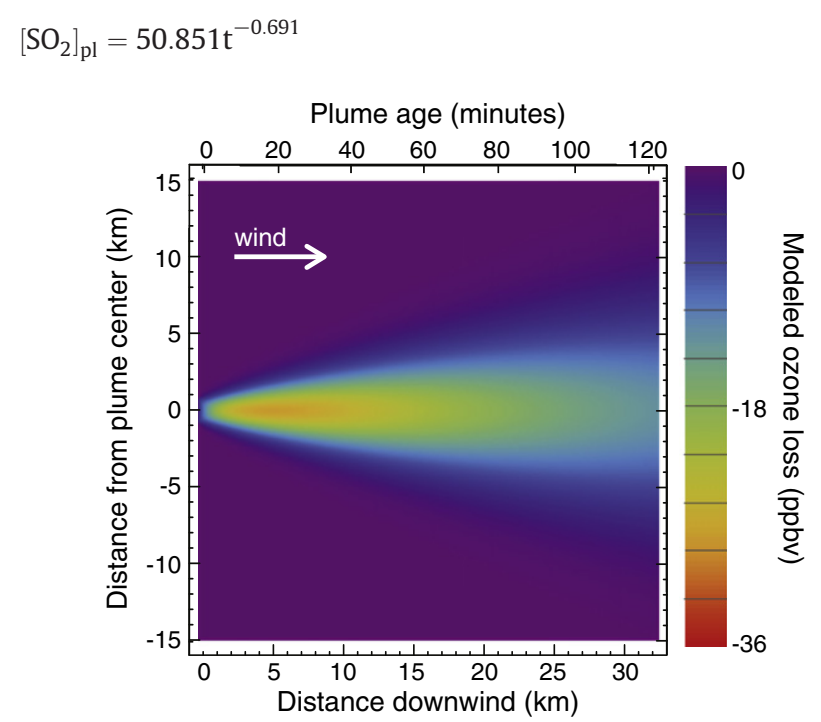

Fig. 12. Results from PlumeChem (Roberts et al., 2009) showing horizontally-resolved model $\mathrm{O}_{3}$ loss in the plume tuned to conditions from June 21, 2010. The model output shows plume dispersion and $\mathrm{O}_{3}$ destruction downwind for comparison to measured values shown in Fig. 10b. 

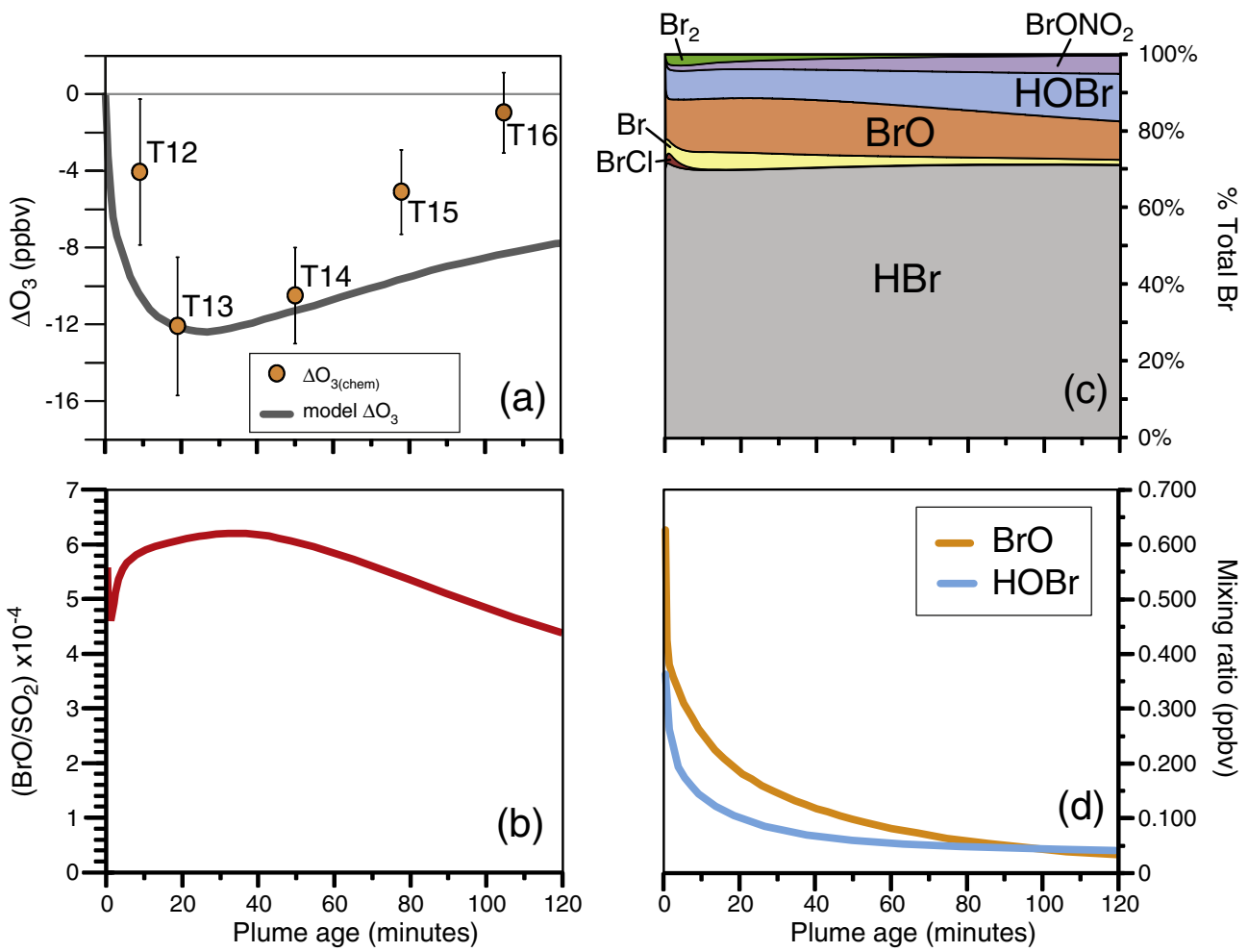

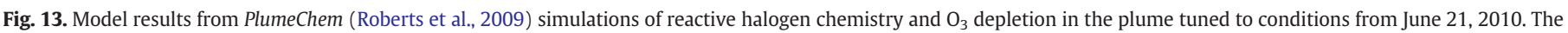

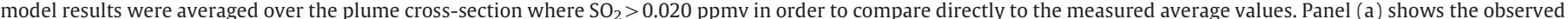

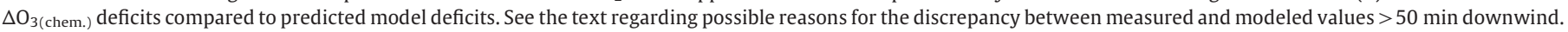

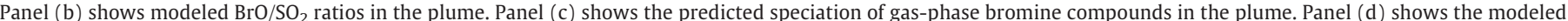

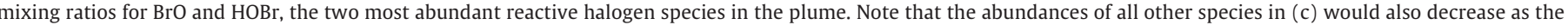
plume dispersed. See Section 5.3.2 for more information.

where $\left[\mathrm{SO}_{2}\right]_{\mathrm{pl}}$ is the average plume $\mathrm{SO}_{2}$ mixing ratio in ppmv and $\mathrm{t}$ is the plume age in seconds (Fig. 11a). We exclude data from traverses 15 and 16 from the regression because the crosswind integrated $\mathrm{SO}_{2}$ concentrations were much lower than those from 12 to 14 $(<1000$ ppmv m; Table 3$)$. As discussed previously, this is likely because we sampled the vertical edge of the plume rather than the center during traverses 15 and 16 . Next, if we assume $\mathrm{SO}_{2}$ is a zerobackground and conservative tracer (this assumption is valid over the short timescale we consider) we can solve for the dilution rate $\mathrm{D}(\mathrm{t})$ by differentiating Eq. (8) to obtain $\mathrm{d}\left[\mathrm{SO}_{2}\right]_{\mathrm{pl}} / \mathrm{dt}$ and substituting both it and Eq. (8) into Eq. (7) $\left(\left[\mathrm{SO}_{2}\right]_{\mathrm{bg}}=0\right)$ to solve for $\mathrm{D}(\mathrm{t})$ :

$\mathrm{D}(\mathrm{t})=\frac{0.691}{\mathrm{t}}$

where t is in seconds (shown in Fig. 11b). Now, using Eqs. (7) and (9), we can model the evolution of any conserved species in the plume with respect to entrainment and mixing of background air. The results for $\mathrm{O}_{3}$, calculated at 1 -second intervals and beginning at $9 \mathrm{~min}$ downwind (i.e. traverse 12), are shown in Fig. 11c.

Several aspects of the model results are notable. First, it shows that the dilution rate rapidly decreased as a non-linear function of time as the plume aged and expanded. Also, the model's trajectory for ambient $\mathrm{O}_{3}$ in the plume is in good agreement with 4 out 5 of the average $\mathrm{O}_{3 \text { (mix) }}$ values for traverses $12-16$ which suggests the derived $D(t)$ is reasonable, especially given that the $\mathrm{O}_{3(\mathrm{mix})}$ values were calculated using an entirely different methodology. Second, the results suggest that early entrainment of low- $\mathrm{O}_{3}$ air had a significant and lasting impact on the overall $\mathrm{O}_{3}$ composition of the plume, but that the plume composition changed very little due to entrainment after about $80 \mathrm{~min}$, as $\mathrm{D}(\mathrm{t})$ flattens out.

The mixing model allows us to draw some inferences about the dynamics of in-plume $\mathrm{O}_{3}$-destroying chemical reactions. The largest $\mathrm{O}_{3}$ depletions occurred about 20-50 min downwind even though the dilution rate was relatively high, which indicates $\mathrm{O}_{3}$-destroying species were produced very rapidly and destroyed $\mathrm{O}_{3}$ very efficiently. In contrast, the projected values from traverses 13 and 14 (19 and 50 min downwind) are consistent with the observed $\mathrm{O}_{3}$ values for traverses 15 and 16 (78 and 105 min downwind) which suggests further significant $\mathrm{O}_{3}$ destruction did not occur beyond $\sim 50$ min downwind. If vigorous chemical $\mathrm{O}_{3}$ destruction were ongoing $50 \mathrm{~min}$ or more downwind, we would expect greater in-plume $\mathrm{O}_{3}$ anomalies as the dilution rate slowed and reduced the supply of ambient $\mathrm{O}_{3}$ into the plume, but this does not appear to be true in this case. However, even without chemical $\mathrm{O}_{3}$ destruction, $\mathrm{O}_{3}$ anomalies as much as 10 ppbv below background could easily exist for several hours or more because of the low dilution rate, which would limit ambient air mixing into the plume.

In order to build on the simple parameterization presented here, in the next section we report results from the PlumeChem model (Roberts et al., 2009), which is a numerical model that simulates reactive halogen formation and $\mathrm{O}_{3}$ depletion in volcanic plumes as they disperse into the atmosphere. The model includes the autocatalytic chemical mechanism for $\mathrm{BrO}$ formation via heterogeneous chemistry as previously outlined (R1-R7) and coupling between $\mathrm{BrO}$ and $\mathrm{NO}_{\mathrm{x}}$ chemistry via $\mathrm{BrONO}_{2}$. Initialization of the model includes consideration of the high-temperature products $\left(\mathrm{HO}_{\mathrm{x}}, \mathrm{Cl}_{\mathrm{x}}, \mathrm{Br}_{\mathrm{x}}\right)$ that form when magmatic gases mix with air at high temperatures and are believed to kick-start BrO chemistry (see Roberts et al., 2009 for discussion). 


\subsubsection{Comparisons with PlumeChem model simulations}

Results from simulations using the PlumeChem model (Roberts et al., 2009) in multi-box mode at $200 \mathrm{~m}$ resolution (200 boxes in horizontal) are shown in Figs. 12 and 13. For these simulations the model parameters were tuned to the observed volcanic and meteorological conditions of the Redoubt Volcano plume on June 21 including wind-speed $(4.4 \mathrm{~m} / \mathrm{s}), \mathrm{SO}_{2}$ emission rate $(370 \mathrm{t} / \mathrm{d})$, and plume dispersion set to match the observed plume width. The volcanic aerosol loading was initialized at $10^{-11} \mu^{2} /\left(\operatorname{molec} \mathrm{SO}_{2}\right), 10 \%$ of the value used by Roberts et al. (2009). High-temperature chemistry in the near-vent plume was approximated by initializing PlumeChem using ArcMean HSC equilibrium model output for a 90:10 magmatic:atmospheric gas mixture at $1000{ }^{\circ} \mathrm{C}$ (see Table 1 in Roberts et al., 2009), with total $\mathrm{Br} / \mathrm{S}$ and total $\mathrm{Cl} / \mathrm{S}$ adjusted to match the observed ratios from the filter packs collected on June 20. Given substantial uncertainty in volcanic sources of $\mathrm{NO}_{\mathrm{x}}$, e.g. as recently discussed by Boichu et al. (2011), the volcanic $\mathrm{NO}_{\mathrm{x}}$ emission was set to zero. The horizontally-resolved model $\mathrm{O}_{3}$ loss in the plume is shown in Fig. 12. The model output was also averaged over the plume crosssection where $\mathrm{SO}_{2}>0.020$ ppmv in order to compare directly to the measured average values (Fig. 13).

The model shows strong agreement in the downwind trend and magnitude of observed $\mathrm{O}_{3}$ depletion, with the maximum deficit $(-30 \mathrm{ppbv})$ occurring in the plume center (Fig. 12) and average $\mathrm{O}_{3}$ deficit reaching -12 ppbv at 20-40 min (Fig. 13a). Beyond $60 \mathrm{~min}$ the simulations appear to overpredict $\mathrm{O}_{3}$ depletion compared to observations, however this is likely due to the above-mentioned sampling of plume edges rather than the center in traverses 15 and 16 . $\mathrm{BrO}$ is produced amongst other forms of reactive bromine $\mathrm{HOBr}$, $\mathrm{BrONO}_{2}, \mathrm{Br}_{2}, \mathrm{BrCl}$ and $\mathrm{Br}$ ) reaching a $\mathrm{BrO} / \mathrm{SO}_{2}$ ratio of $6 \cdot 10^{-4}$ (average) at $20-40$ min downwind (equivalent to $14 \%$ of total $\mathrm{Br}$ ), beyond which $\mathrm{BrO} / \mathrm{SO}_{2}$ decreases (Fig. 13b).

The model demonstrates that approximately $30 \%$ of total bromine is converted to reactive forms (Fig. 13c). This contrasts with simulations of more concentrated volcanic plumes that showed rapid and near-complete conversion of $\mathrm{HBr}$ to reactive bromine (Bobrowski et al., 2007; Roberts et al., 2009; von Glasow, 2010), and supports our earlier analysis of plume chemistry dynamics: the early, more concentrated plume undergoes rapid reactive halogen formation and also efficient cycling between $\mathrm{BrO}$ and $\mathrm{Br}$ leading to rapid $\mathrm{O}_{3}$ loss within the first $30 \mathrm{~min}$. The average concentrations of all species decrease as the plume disperses further downwind and as a result, the rate of chemical cycling between $\mathrm{Br}$ and $\mathrm{BrO}$ decreases, leading to slower $\mathrm{O}_{3}$ destruction. Nevertheless, the continued presence of reactive bromine shown by the model indicates that reactive halogens persist at elevated levels relative to ambient air beyond the 2 hour simulation (Fig. 13d). These initial PlumeChem model results demonstrate a strong capability to reproduce the main features of the observations and further model simulations and analysis will be included in a forthcoming publication (Roberts et al., in prep.).

\subsection{Summary of measurement and model results}

Together the measurement and model results from June 21 suggest that a combination of entrainment of low- $\mathrm{O}_{3}$ air into the plume and auto-catalytic bromine chemistry can explain the timing and magnitude of the observed $\mathrm{O}_{3}$ deficits. The observations from August 19 are consistent with a catalytic $\mathrm{O}_{3}$ destruction mechanism like that implemented in the model because the observed $\mathrm{O}_{3 \text { (chem) }}$ deficit during traverse 2 is relatively large $\left(\Delta \mathrm{O}_{3 \text { (chem) }}=-5.9 \pm 3.6 \mathrm{ppbv}, \mathrm{p}=0.10\right)$ compared to the abundance of $\mathrm{BrO}$ (on the order of $10 \mathrm{~s}$ of pptv) detected at a similar location downwind. However, because $\mathrm{BrO}$ is only one of several reactive bromine species including $\mathrm{Br}$ radicals, $\mathrm{Br}_{2}$, $\mathrm{BrCl}, \mathrm{BrNO}_{2}, \mathrm{BrONO}_{2}$, and $\mathrm{HOBr}$ thought to be present in volcanic plumes during the bromine explosion process, the total concentration of gaseous bromine species in the plume at any given time may easily be an order of magnitude higher than the measured $\mathrm{BrO}$ concentration and much greater than that of background ambient air.

Unlike polar $\mathrm{O}_{3}$ depletion events that occur near the surface, passive volcanic degassing can release gases and particles directly into the free troposphere where they can be transported long distances. In particular, our results suggest that non-explosive volcanic degassing in Alaska can result in the release of reactive halogen species to the subarctic troposphere. Further work is needed to better understand the production of reactive halogen species under different volcanic and environmental conditions as well as to explore related aspects of volcanic plume chemistry, such as the impacts of reactive halogen chemistry on $\mathrm{Hg}$ speciation in volcanic plumes.

\section{Conclusions}

We traced the rapid halogen-mediated chemical evolution of volcanic emissions from Redoubt Volcano during the first $\sim 2 \mathrm{~h}$ after volcanic volatiles were released to the atmosphere. We used ground-based, airborne in situ, and airborne remote sensing techniques. Our measurements include the first observations of $\mathrm{Br}$ and I degassing from an Alaskan volcano, the first study of $\mathrm{O}_{3}$ evolution in a volcanic plume, and the first detection of $\mathrm{BrO}$ in the tropospheric plume of a passively degassing Alaskan volcano. The $\mathrm{O}_{3}$ measurements were facilitated using a method we devised that employed ordinary, readily available equipment. The measurements show that $\mathrm{O}_{3}$ mixing ratios in volcanic plumes are highly variable and reflect the mixing and entrainment of ambient air into the plume in addition to in-plume chemical processes. We also presented the first detailed spatially-resolved comparison of measured and modeled $\mathrm{O}_{3}$ depletion in a volcanic plume. Simulations with the PlumeChem model (Roberts et al., 2009), which includes the autocatalytic chemical mechanism for in-plume BrO formation, kickstarted by high-temperature products, were able to reproduce both the timing and magnitude of in-plume $\mathrm{O}_{3}$ deficits. Thus, our results are in general accord with models of reactive bromine chemistry and $\mathrm{O}_{3}$ destruction in volcanic plumes (Bobrowski et al., 2007; Roberts et al., 2009; von Glasow, 2010) that propose BrO and other reactive halogen species are formed by heterogenous and photochemical processes. While our results are not necessarily unexpected, they show that field studies must pay careful attention to variations in the composition of ambient air entrained into volcanic plumes in order to unambiguously attribute observed $\mathrm{O}_{3}$ anomalies to specific chemical or dynamic processes. Our data suggest that non-explosive volcanic degassing in Alaska can result in the release of reactive halogen species to the subarctic troposphere, with the potential for long-distance transport.

\section{Acknowledgments}

We warmly acknowledge Gaetano Giudice and Marco Liuzzo for help with the fieldwork as well as logistical assistance from Mike Doukas, Game McGimsey, Kate Bull, and John Paskievitch. We thank fixed-wing pilot Steve Jones and helicopter pilot John Fryer for their outstanding work in support of this study. Two anonymous reviewers and Terry Gerlach provided detailed, first-rate reviews that helped to greatly improve the manuscript. Major funding for this work was provided by the USGS Volcano Science Center. In addition, T.J.R thanks the Norwegian Polar Institute for support, T.L. acknowledges support from American Recovery and Reinvestment Act funds for three months during 2010, and field work expenses in Alaska for A.A. were covered by CO.RI. 2008 grant (granted by Università di Palermo). Any use of trade, product, or firm names is for descriptive purposes only and does not imply endorsement by the U.S. Government.

\section{Appendix A. Supplementary data}

Supplementary data to this article can be found online at http:// dx.doi.org/10.1016/j.jvolgeores.2012.04.023. 


\section{References}

Aiuppa, A., Federico, C., Franco, A., Giudice, G., Gurrieri, S., Inguaggiato, S., Liuzzo, M. McGonigle, A.J.S., Valenza, M., 2005. Emission of bromine and iodine from Mount Etna volcano. Geochemistry, Geophysics, Geosystems 6 (Q08008). http:// dx.doi.org/10.1029/2005GC000965.

Bani, P., Oppenheimer, C., Tsanev, V., Carn, S., Cronin, S., Crimp, R., Calkins, J., Charley, D., Lardy, M., Roberts, T., 2009. Surge in sulphur and halogen degassing from Ambrym volcano, Vanuatu. Bulletin of Volcanology 71, 1159-1168.

Bobrowski, N., Platt, U., 2007. $\mathrm{SO}_{2} / \mathrm{BrO}$ ratios studied in five volcanic plumes. Journal of Volcanology and Geothermal Research 166, 147-160.

Bobrowski, N., Hönniger, G., Galle, B., Platt, U., 2003. Detection of bromine monoxide in a volcanic plume. Nature 423, 273-276.

Bobrowski, N., von Glasow, R., Aiuppa, A., Inguaggiato, S., Louban, I., Ibrahim, O.W., Platt, U., 2007. Reactive halogen chemistry in volcanic plumes. Journal of Geophysical Research 112 (D06), 311. http://dx.doi.org/10.1029/2006JD007206.

Bogumil, K., Orphal, J., Homann, T., Voigt, S., Spietz, P., Fleischmann, O.C., Vogel, A Hartmann, M., Bovensmann, H., Frerick, J., Burrows, J.P., 2003. Measurements of molecular absorption spectra with the SCIAMACHY pre-flight model: instrument characterization and reference data for atmospheric remote sensing in the 230-2380 $\mathrm{nm}$ region. Journal of Photochemistry and Photobiology A: Chemistry 157, 167-184.

Boichu, M., Oppenheimer, C., Roberts, T.J., Tsanev, V., Kyle, P., 2011. On bromine, nitrogen oxides and ozone depletion in the tropospheric plume of Erebus volcano (Antarctica). Atmospheric Environment 45, 3856-3866.

Bull, K.F., Buurman, H., 2013. An overview of the 2009 eruption of Redoubt Volcano, Alaska. Journal of Volcanology and Geothermal Research 259, 2-15.

Bull, K.F., Anderson, S.W., Diefenbach, A.K., Wessels, R.L., Henton, S.M., 2013. Emplacement of the final lava dome of the 2009 eruption of Redoubt Volcano, Alaska. Journal of Volcanology and Geothermal Research 259, 334-348.

Carn, S.A., Froyd, K.D., Anderson, B.E., Wennburg, P., Crounse, J., Spencer, K., Dibb, J.E., Krotkov, N.A., Browell, E.V., Hair, J.W., Diskin, G., Sachse, G., Vay, S.A., 2011. In situ measurements of tropospheric volcanic plumes in Ecuador and Colombia during TC ${ }^{4}$. Journal of Geophysical Research 116 (D00J24). http://dx.doi.org/10.1029/ 2010JD014718.

Chosson, F., Paoli, R., Cuenot, B., 2008. Ship plume dispersion rates in convective boundary layer chemistry models. Atmospheric Chemistry and Physics 8, 4841-4853.

Diefenbach, A.K., Bull, K.F., Wessels, R.L., McGimsey, R.G., 2013. Photogrammetric monitoring of lava dome growth during the 2009 eruption of Redoubt Volcano. Journal of Volcanology and Geothermal Research 259, 308-316.

Doukas, M.P., 2002. A new method for GPS-based wind speed determinations during airborne volcanic plume measurements. U. S. Geological Survey Open-File Report 02-395 (13 pp.).

Doukas, M.P., McGee, K.A., 2007. A compilation of gas emission-rate data from volcanoes of Cook Inlet (Spurr, Crater Peak, Redoubt, Iliamna, and Augustine) and Alaska Peninsula (Douglas, Fourpeaked, Griggs, Mageik, Martin, Peulik, Ukinrek Maars, and Veniaminof), Alaska, from 1995-2006. U.S. Geological Survey Open-File Report 2007-1400 (13 pp.)

Fruchter, J.S., Robertson, D.E., Evans, J.C., Olsen, K.B., Lepel, E.A., Laul, J.C., Abel, K.H., Sanders, R.W., Jackson, P.O., Wogman, N.S., Perkins, R.W., Van Tuyl, H.H., Beauchamp, J.W Shade, J.W., Daniel, J.L, Erikson, R.L., Sehmel, G.A., Lee, R.N., Robinson, A.V., Moss, O.R., Briant, J.K., Cannon, W.C., 1980. Mount St. Helens Ash from the 18 May 1980 Eruption: Chemical, Physical, Mineralogical and Biological properties. Science 209, 1116-1125. http://dx.doi.org/10.1126/science.209.4461.1116.

Gerlach, T.M., 2004. Volcanic sources of tropospheric ozone-depleting trace gases. Geochemistry, Geophysics, Geosystems 5 (Q09007). http://dx.doi.org/10.1029/ 2004GC000747.

Gerlach, T.M., Delgado, H., McGee, K.A., Doukas, M.P., Venegas, J.J., Cardenas, L., 1997. Application of the LI-COR CO2 analyzer to volcanic plumes: a case study, Volcan Popocatepetl, Mexico, June 7 and 10, 1995. Journal of Geophysical Research 102, 8005-8019.

Heue, K.-P., Brenninkmeijer, C.A.M., Baker, A.K., Rauthe-Schöch, A., Walter, D., Wagner, T., Hörmann, C., Sihler, H., Dix, B., Frieß, U., Platt, U., Martinsson, B.G., van Velthoven, P.F.J., Zahn, A., Ebinghaus, R., 2011. $\mathrm{SO}_{2}$ and $\mathrm{BrO}$ observation in the plume of the Eyjafjallajökull volcano 2010: CARIBIC and GOME-2 retrievals. Atmospheric Chemistry and Physics 11 (6), 2973-2989.

Hobbs, P., Tuell, J., Hegg, D., Radke, L., Eltgrowth, L., 1982. Particles and gases in the emissions from the 1980-1981 volcanic eruptions of Mt. St. Helens. Journal of Geophysical Research 87, 11062-11086.

Horton, K.A., Williams-Jones, G., Garbeil, H., Elias, T., Sutton, A.J., Mouginis-Mark, P. Porter, J.N., Clegg, S., 2006. Real-time measurement of volcanic $\mathrm{SO}_{2}$ emissions: validation of a new UV correlation spectrometer (FLYSPEC). Bulletin of Volcanology 68, 323-327.

Kelly, P., et al., in preparation. Airborne detection of gaseous elemental mercury in the plumes of three Alaskan Volcanoes (Redoubt, Mageik, Martin).

Kern, C., Sihler, H., Vogel, L., Rivera, C., Herrera, M., Platt, U., 2009. Halogen oxide measurements at Masaya volcano, Nicaragua using active long path differential optica absoption spectroscopy. Bulletin of Volcanology 71, 659-670.

Kern, C., Deutschmann, T., Vogel, L., Wöhrbach, M., Wagner, T., Platt, U., 2010. Radiative transfer corrections for accurate spectroscopic measurements of volcanic gas emissions. Bulletin of Volcanology 72, 233-247.

Lopez, T., Carn, S., Werner, C., Fee, D., Kelly, P., Doukas, M., Pfeffer, M., Webley, P.W. Cahill, C., Schneider, D., 2013. Evaluation of Redoubt Volcano's sulfur dioxide emissions by the Ozone Monitoring Instrument. Journal of Volcanology and Geothermal Research 259, 290-307.

McGee, K.A., Doukas, M.P., Gerlach, T.M., 2001. Quiescent hydrogen sulfide and carbon dioxide degassing from Mount Baker, Washington. Geophysical Research Letters 28 (23), 4479-4482.
Miller, T.P., McGimsey, R.G., Richter, D.H., Riehle, J.R., Nye, C.J., Yount, M.E., Dumoulin, J.A., 1998. Catalog of the historically active volcanoes of Alaska. US Geological Survey Open-File Report 98-0582 (104 pp.).

Oppenheimer, C., Tsanev, V.I., Braban, C.F., Cox, R.A., Adams, J.W., Aiuppa, A., Bobrowski, N., Delmelle, P., Barclay, J., McGonigle, A.J.S., 2006. BrO formation in volcanic plumes. Geochimica et Cosmochimica Acta 70, 2935-2941.

Oppenheimer, C., Kyle, P., Eisele, F., Crawford, J., Huey, G., Tanner, D., Brady, K., Mauldin, L., Blake, D., Beyersdorf, A., Buhr, M., Davis, D., 2010. Atmospheric chemistry of an Antarctic volcanic plume. Journal of Geophysical Research 115 (D04303). http:// dx.doi.org/10.1029/2009JD011910.

Pfeffer, M.A., Doukas, M.P., Werner, C.A., Evans, W.C. 2013. Airborne filter pack measurements of $\mathrm{S}$ and $\mathrm{Cl}$ in the plume of Redoubt Volcano, Alaska February-May 2009. Journal of Volcanology and Geothermal Research 259, 285-289.

Platt, U., Stutz, J., 2008. Differential Optical Absorption Spectroscopy - Principles and Applications. Springer. (597 pp.).

Pyle, D., Mather, T.A., 2009. Halogens in igneous processes and their fluxes to the atmosphere and oceans from volcanic activity: a review. Chemical Geology 263, 110-121.

Roberts, T. Braban, C. Martin, R, Oppenheimer C Adams, J., Cox, R. Jones, R., Griffiths, P., 2009. Modelling reactive halogen formation and ozone depletion in volcanic plumes. Chemical Geology 263, 151-163.

Roberts, T.J., et al., in preparation. Modelling the formation of reactive halogens and ozone depletion in the tropospheric plume of Redoubt Volcano, Alaska.

Rufus, J., Stark, G., Smith, P.L., Pickering, J.C., Thorne, A.P., 2003. High-resolution photoabsorption cross section measurements of $\mathrm{SO}_{2}, 2: 220$ to $325 \mathrm{~nm}$ at $295 \mathrm{~K}$. Journal of Geophysical Research 108 (5011). http://dx.doi.org/10.1029/2002JE001931.

Sander, S.P., Friedl, R.R., Golden, D.M., Kurylo, M.J., Moortgat, G.K., Keller-Rudek, H., Wine, P.H., Ravishankara, A.R., Kolb, C.E., Molina, M.J., Finlayson-Pitts, B.J., Huie, R.E., Orkin, V.L., 2006. Chemical kinetics and photochemical data for use in atmospheric studies, evaluation no. 15. Jet Propulsion Laboratory Publication 06-2 (523 pp.).

Sawyer, G.M., Salerno, G.G., Le Blond, J., Martin, R.S., Spampinato, L., Roberts, T., Mather, T.A., Witt, M., Tsanev, V.I., Oppenheimer, C., 2011. Gas and aerosol emissions from Villarrica volcano, Chile. Journal of Volcanology and Geothermal Research 203, 62-75.

Schumann, U., Weinzierl, B., Reitebuch, O., Schlager, H., Minikin, A., Forster, C., Baumann, R., Sailer, T., Graf, K., Mannstein, H., Voight, C., Rahm, S., Simmet, R., Scheibe, M., Lichtenstern, M. Stock, P. Rüba, H. Schäuble, Tafferner, A, Rautenhaus, M., Gerz, T., Ziereis, H., Krautstrunk, M., Mallaun, C., Gayet, J.-F., Lieke, K., Kandler, K., Ebert, M., Weinbruch, S., Stohl, A., Gasteiger, J., Groß, S., Freudenthaler, V., Wiegner, M., Ansmann, A., Teshce, M., Olafsson, H., Sturm, K., 2011. Airborne observations of the Eyjafjalla volcano ash cloud over Europe during air space closure in April and May 2010. Atmospheric Chemistry and Physics 11, 2245-2279.

Simpson, W.R., von Glasow, R., Riedel, K., Anderson, P., Ariya, P., Bottenheim, J., Burrows, J., Carpenter, L.J., Frieß, U., Goodsite, M.E., Heard, D., Hutterli, M., Jacobi, H.-W., Kaleschke, L., Neff, B., Plane, J., Platt, U., Richter, A., Roscoe, H., Sander, R., Shepson, P., Sodeau, J., Steffen, A., Wagner, T., Wolff, E., 2007. Halogens and their role in polar boundarylayer ozone depletion. Atmospheric Chemistry and Physics 7, 4375-4418.

Stith, J.L., Hobbs, P.V., Radke, L.F., 1978. Airborne particle and gas measurements in the emissions from six volcanoes. Journal of Geophysical Research 83 (C8), 4009-4017. http://dx.doi.org/10.1029/JC083iC08p04009.

Stoiber, R.E., Malinconico, L.L., Williams, S.N., 1983. Use of the correlation spectrometer at volcanoes. In: Tazieff, H., Sabroux, J.C. (Eds.), Forecasting Volcanic Events. Elsevier, pp. 424-444

Symonds, R.B., Rose, W.I., Gerlach, T.M., Briggs, P.H., Harmon, R.S., 1990. Evaluation of gases, condensates, and SO2 emissions from Augustine volcano, Alaska: the degassing of a Cl-rich volcanic system. Bulletin of Volcanology 52, 355-374.

Theys, N., Van Roozendael, M., Dils, B., Hendrick, F., Hao, N., Mazière, De, 2009. First satellite detection of volcanic bromine monoxide emission after the Kasatochi eruption. Geophysical Research Letters 36 (L03809). http://dx.doi.org/10.1029/2008GL036552.

Vance, A., McGonigle, A.J.S., Aiuppa, A., Stith, J.L., Turnbull, K., von Glasow, R., 2010. Ozone depletion in tropospheric volcanic plumes. Geophysical Research Letters 37 (L22802). http://dx.doi.org/10.1029/2010GL044997.

Vandaele, A.C., Hermans, C., Fally, S., 2009. Fourier transform measurements of $\mathrm{SO}_{2}$ absorption cross sections: II. Temperature dependence in the $29000-44000 \mathrm{~cm}^{-1}$ (227-345 nm) region. Journal of Quantitative Spectroscopy and Radiative Transfer $110,2115-2126$

von Glasow, R., 2010. Atmospheric chemistry in volcanic plumes. Proceedings of the National Academy of Sciences 107, 6594-6599.

von Glasow, R., Lawrence, M.G., Sander, R., Crutzen, P.J., 2003. Modeling the chemical effects of ship exhaust in the cloud-free marine boundary layer. Atmospheric Chemistry and Physics 3, 233-250.

von Glasow, R., Bobrowski, N., Kern, C., 2009. The effects of volcanic eruptions on atmospheric chemistry. Chemical Geology 263, 131-142.

Warneck, P., 2000. Chemistry of the Natural Atmosphere, 2nd ed. Academic Press. (927 pp.).

Werner, C., Evans, W.C., Kelly, P.J., McGimsey, R., Pfeffer, M., Doukas, M., Neal, C., 2012. Deep magmatic degassing versus scrubbing: Elevated $\mathrm{CO}_{2}$ emissions and $\mathrm{C} / \mathrm{S}$ in the lead-up to the 2009 eruption of Redoubt Volcano Alaska. Geochemistry, Geophysics, Geosystems 13, 003015. http://dx.doi.org/10.1029/2011GC003794.

Werner, C., Kelly, P.J., Doukas, M., Lopez, T., Pfeffer, M., McGimsey, R.G., Neal, C.A., 2013. Degassing of $\mathrm{CO}_{2}, \mathrm{SO}_{2}$, and $\mathrm{H}_{2} \mathrm{~S}$ associated with the 2009 eruption of Redoubt Volcano, Alaska. Journal of Volcanology and Geothermal Research 259, 270-284.

Witt, M.L.I., Mather, T.A., Pyle, D.M., Aiuppa, A., Bagnato, E., Tsanev, V.I., 2008. Mercury and halogens from Masaya and Telica volcanoes, Nicaragua. Journal of Geophysical Research Solid Earth 113, B06203. http://dx.doi.org/10.1029/2007JB005401.

Wu, C.Y.R., Yang, B.W., Chen, F.Z., Judge, D.L., Caldwell, J., Trafton, L.M., 2000. Measurements of high-, room-, and low-temperature photoabsorption cross sections of $\mathrm{SO}_{2}$ in the 2080 - to 2950 - $\AA$ region, with application to Io. Icarus $145,289-296$. 